\title{
MÁRIO DE ANDRADE CRONISTA DE SÃO PAULO NOS PRIMÓRDIOS DO MODERNISMO
}

\author{
Telê Ancona Lopez \\ teleal@usp.br
}

Para Marcos e Tatiana

Imensa e polimorfa é a trajetória de Mário de Andrade jornalista. Compõe-se de artigos, crônicas, ensaios, poemas, contos e excertos de romances, concentrando-se na grande imprensa e em periódicos especializados de São Paulo e do Rio de Janeiro. Não desdenha tabloides, e ramifica-se na colaboração esporádica em jornais e revistas de outras cidades brasileiras, bem como da Argentina e do Uruguai. Está em todas as revistas do nosso modernismo; assume seções e colunas; viceja em séries também. Apenas a morte a interrompe, em 25 de fevereiro, 1945. No presente estudo, votado a um momento singular na produção do cronista, o tracejar do modernismo em 1920-1921, valho-me especialmente do relato do Arquivo Mário de Andrade, hoje no Instituto de Estudos Brasileiros da Universidade de São Paulo.

No arquivo, dois álbuns de recortes, volumosos, encadernação em pano-couro preto, afetada pelo tempo, classificados na série Matérias extraídas de periódicos, recolhem uma parcela pequena, porém significativa do jornalismo mariodeandreadiano entre 1915 e 1935: críticas de literatura e música, crônicas, contos e poemas, um discurso e uma entrevista. A intenção de preservar materializa-se nos recortes colados com goma arábica, sem obediência à cronologia, por Maria de Lourdes de 
Morais Andrade, entre 1930 e 1935, quando foi uma espécie de secretária do irmão'.

Nos dois volumes que testemunham, raras vezes, a supervisão da pena do interessado, o conjunto dos documentos assegura, como é próprio dos fundos pessoais, aspectos da história de vida do signatário. Neste caso, Mário de Andrade, já um escritor reconhecido, não deixa que se perca seu jornalismo de juventude, nem parcela de um dos melhores períodos de sua crônica, a coluna “Táxi”, no Diário Nacional, de 1929 a 1932; endossa ou suscita a atividade de reunir, consignar proveniência e datas, mesmo aceitando a falta de rigor na disposição dos textos. Aliás, em outros álbuns em seu arquivo, muito mais antigos, é ele quem apanha textos de outros autores e reportagens sobre assuntos de seu interesse, cola com esmero os recortes, mas se esquece da ordem cronológica. De toda forma, nos dois álbuns, a lacunar e imperfeita organização desafia a precariedade do jornalismo. A desordem cronológica cria um divertido caleidoscópio na colagem de fragmentos que reafirma, involuntariamente, a mobilidade da memória. Nessa edificação sui generis, a obra imatura de Mário tem seu sítio².

Inaugura esse dossiê do jornalista, no primeiro álbum, o artiguete "No Conservatório Dramático e Musical - Sociedade de Concertos Clássicos”, impresso sem assinatura. O autor repõe a tinta preta, na beira do recorte, a tímida inicial " $\mathrm{M}$ " e distingue o diário paulistano $O$ Commercio do dia 11 de novembro, 1915. Manifestação isolada, é seguida, em julho de 1918, pela atuação do novel crítico musical e cronista n'A Gazeta. No ano anterior, Mário de Andrade publicara, sob o pseudônimo Mário Sobral, Há uma gota de sangue em cada poema, livro de cunho pacifista e cristão, no qual esboçara o verso harmônico e certas soluções renovadoras. E, naquele mesmo 1917, estivera na exposição de pintura moderna de Anita Malfatti, acontecimento decisivo que lhe consolidara a importância das vanguardas na arte do século XX. Outros recortes, colados com alguma proximidade nas páginas do álbum, revelam a gradativa afirmação de um nome e a abertura de espaços para ele, no período 1918-1921. "Mario Moraes Andrade", "Mario de Moraes Andrade", "Mario de Andrade" ou pseudônimos, como "Don José”, assinam poemas, crônicas, críticas e

1. As datas-limite 1930 e 1935 advém das anotações da moça na beira dos recortes e na superfície das folhas. Ao ficar noiva, desistiu da ocupação. Mais tarde, a letra bem desenhada do marido dela, Eduardo Ribeiro dos Santos Camargo, repetiu fontes em boa parte das páginas.

2. Na organização do Arquivo Mário de Andrade no IEB-USP, a pesquisa elaborou dois índices para uso dos consulentes, registrando a organização original e constituindo a sequência. A consulta é feita no microfilme. 
artigos que advêm de páginas em preto e branco de grandes e pequenos jornais e, várias vezes, de páginas impressas em cor, com cercaduras art deco, das revistas paulistanas Miscelânea, O Eco, A Cigarra, A Garoa, e da carioca Illustração Brazileira. Todavia, os textos tirados desses magazines não equivalem à participação integral do escritor nos mesmos, onde figura, nesses quatro anos, número muito maior de colaborações. Essa amostragem nos recortes confirma a pesquisa pioneira de Mário da Silva Brito, em 1955, na História do modernismo brasileiro, que situa Mário de Andrade entre os "avanguardistas" de São Paulo, na cerrada militância jornalística que começa em 1920 e se intensifica em 1921, em prol da renovação artística brasileira. Mário, como Menotti del Picchia, Oswald de Andrade, Guilherme e Tácito de Almeida, encarrega-se da difusão das ideias que culminam na Semana de Arte Moderna, em fevereiro de 1922.

Nesse rumo, aparecem, no primeiro álbum, três das cinco importantes crônicas que constituem a série "De São Paulo", divulgada entre novembro de 1920 e maio de 1921 na Illustração Brazileira, revista ausente do acervo da biblioteca do escritor. São sucedidas, no Jornal do Comércio, por "Futurista?", resposta de 6 junho de 1921 ao artigo de Oswald de Andrade, no mesmo diário, "Meu poeta futurista", que fizera Mário conhecido na cidade em 21 de maio, e com escândalo. Pertencer à escola de Marinetti e perpetrar versos modernistas mereciam, então, atestado de loucura.

Na primeira "De São Paulo", o modernista, que se ali se impõe como estudioso da arte moderna, sabe armar pontes com a arte do passado, da mesma forma que, em outra série, "A arte religiosa no Brasil", do mesmo ano na Revista do Brasil, ao se mover no terreno do barroco, vincula-se à modernidade. Ausente do álbum preto, esse primeiro conjunto de textos de cunho ensaístico de quem brilhará como historiador da nossa arte provém de pesquisa despertada pelas conferências do arquiteto Ricardo Severo, em 1914-1915, na Sociedade de Cultura Artística. A hipótese fundamenta-se na separata com autógrafo do autor, $A$ arte tradicional brasileira: a casa e o templo3, guardada pelo jovem professor que, em junho de 1919, certamente depois de muita leitura, havia mergulhado no barroco mineiro. Palmilhara igrejas, conventos e capelas; em Mariana, visitando Alphonsus de Guimaraens, garantira-lhe estar se preparando como conferencista ${ }^{4}$. Dito e feito. Em $1^{\text {o }}$ de novembro de 1919, a Cigarra

3. A publicação, na biblioteca do escritor, é da própria Sociedade de Cultura Artística, em 1916; Mário de Andrade era sócio-fundador dessa entidade estruturada na Pauliceia, em 1911.

4. V. nota 27 de Mário de Andrade/ Manuel Bandeira: Cartas a Alphonsus de Guimaraens Filho, edição preparada pelo segundo destinatário (São Paulo): Duas Cidades, 1974. 
(a 6, no 123) trouxera "O Triumpho eucharistico de 1733 (Trecho duma conferência a realizar-se na Congregação da I[maculada] C[onceição] de Santa Efigênia)", paráfrase de texto setecentista que, repetida em janeiro do ano seguinte, instala a série de quatro artigos na revista de Paulo Prado e Monteiro Lobato. Nos artigos, as impressões de um viajante imaginário misturam-se à análise minuciosa, adiantando aquilo que o escritor denominará crônica crítica, na década de 1940; perfazem, na realidade, um ensaio dividido em quatro partes, nos números 49, 50, $52 \mathrm{e}$ 54 da Revista do Brasil, em janeiro, fevereiro, abril e junho de 1920.

"A arte religiosa no Brasil" assemelha-se às crônicas "De São Paulo" no que tange à pletora de erudição e à postura modernista de primeira hora, ostensiva no uso da língua portuguesa falada no Brasil e na valorização da nacionalidade. Nesse sentido, à defesa do projeto neocolonial para nossa arquitetura, advogando o despojamento das construções e a adequação ao clima, decalcado em Severo, a série acrescenta a denúncia da mistura de estilos, inconveniência que mascarava a Pauliceia em cidade europeia. $\mathrm{O}$ articulista se interessa pelos projetos de Gaudí e de outros europeus contemporâneos, ao mesmo tempo em que refuta a imitação tácita da geometria secessionista alemã ou do futurismo italiano. Mais tarde, na vontade talvez de republicar, Mário rasura os textos nos seus exemplares dos números da revista 5 . E comenta na margem do primeiro artigo:

É uma coisa inconcebível como o meu espírito se desenvolveu tardonho e lerdo. Esta hórrida conferência foi escrita em 1918 ou 1919. Eu tinha já 26 ou 25 anos. Mas o que está aqui parece coisa de ginasiano pedante, indigestado, sem cultura mas lido, com algum ralo lampejo de espírito crítico original, aos 16 anos de idade e suas espinhas (KRONBAUER, 1993, p. 15).

Fraco lampejo para o impiedoso crítico de si mesmo, mas etapa significativa nos trajetos de um modernista que, em fevereiro de 1921, na terceira crônica "De São Paulo", no no 6 da Illustração Brazileira, reitera ideias externadas em "A arte religiosa no Brasil" e sua adesão à campanha em favor do estilo neocolonial, lançada por Ricardo Severo.

p. 29). O organizador transcreve trecho de carta de 15 de julho de 1919, em que o pai lhe conta os planos do moço poeta que o visitara em Mariana.

5. O novo texto que advém da junção das rasuras à matéria impressa é apresentado por Claudete Kronbauer em "Mário de Andrade: Um texto de juventude", na edição crítica que realizou de $A$ arte religiosa no Brasil (São Paulo: Giordano/ Experimento, 1993). 


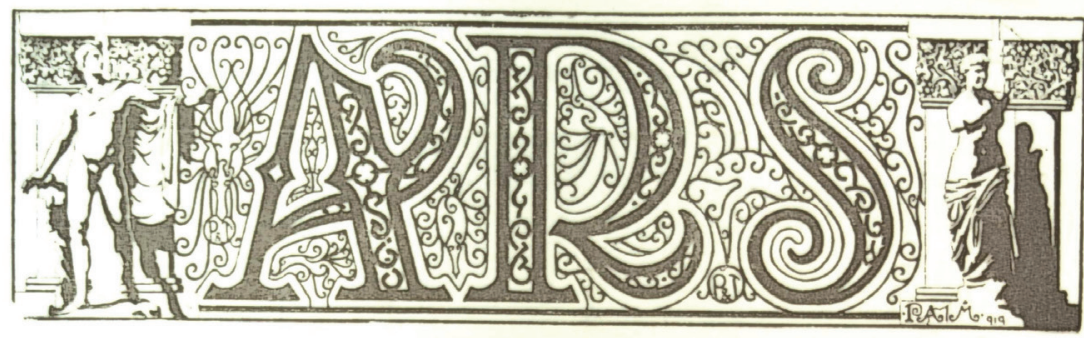

\section{UICTOR BRECHERET}
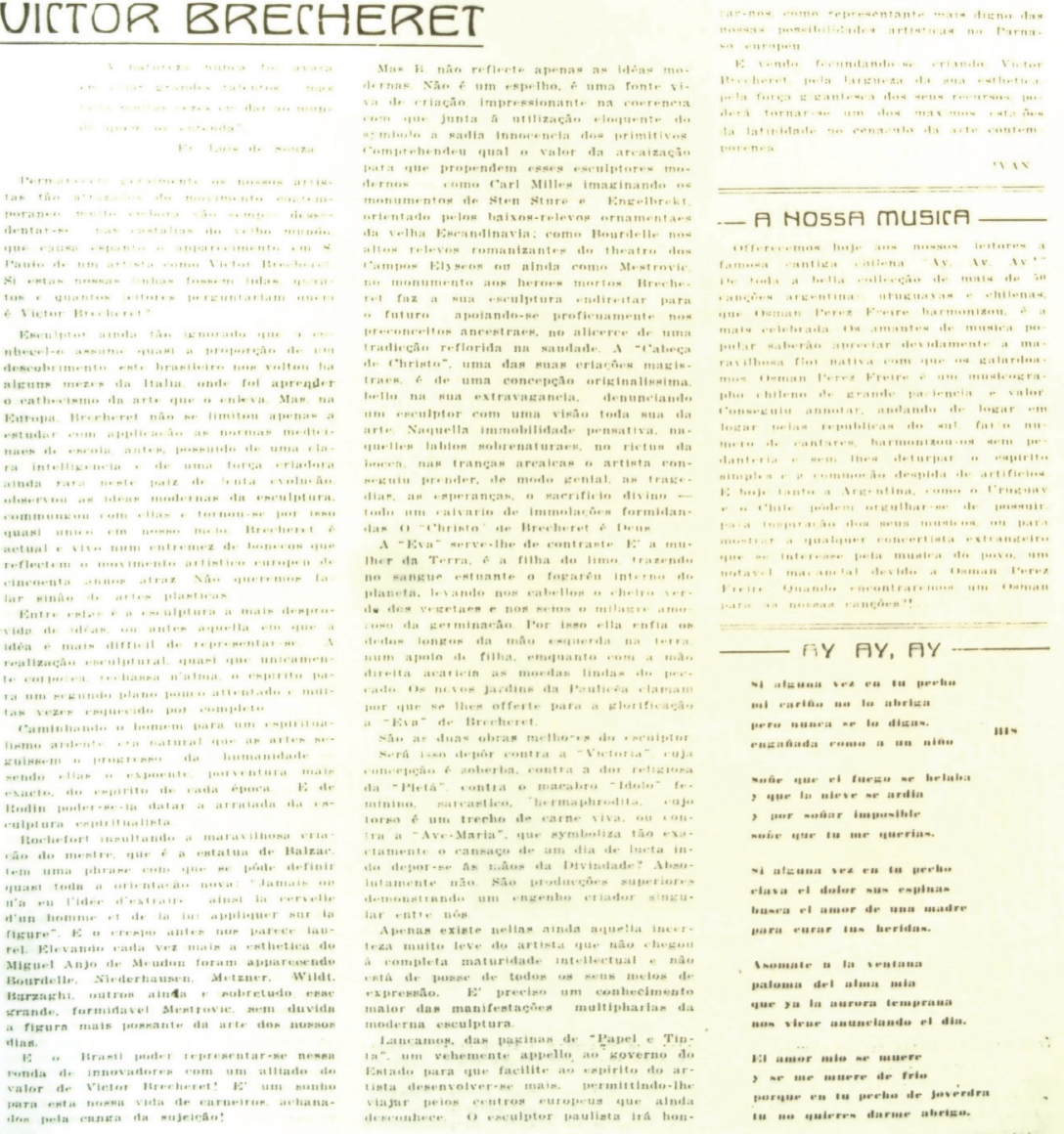

Artigo de Ivan [Mário de Andrade] em Papel e Tinta, São Paulo, no 2, jun. 1920. 
56 - Remate de Males 33.1-2

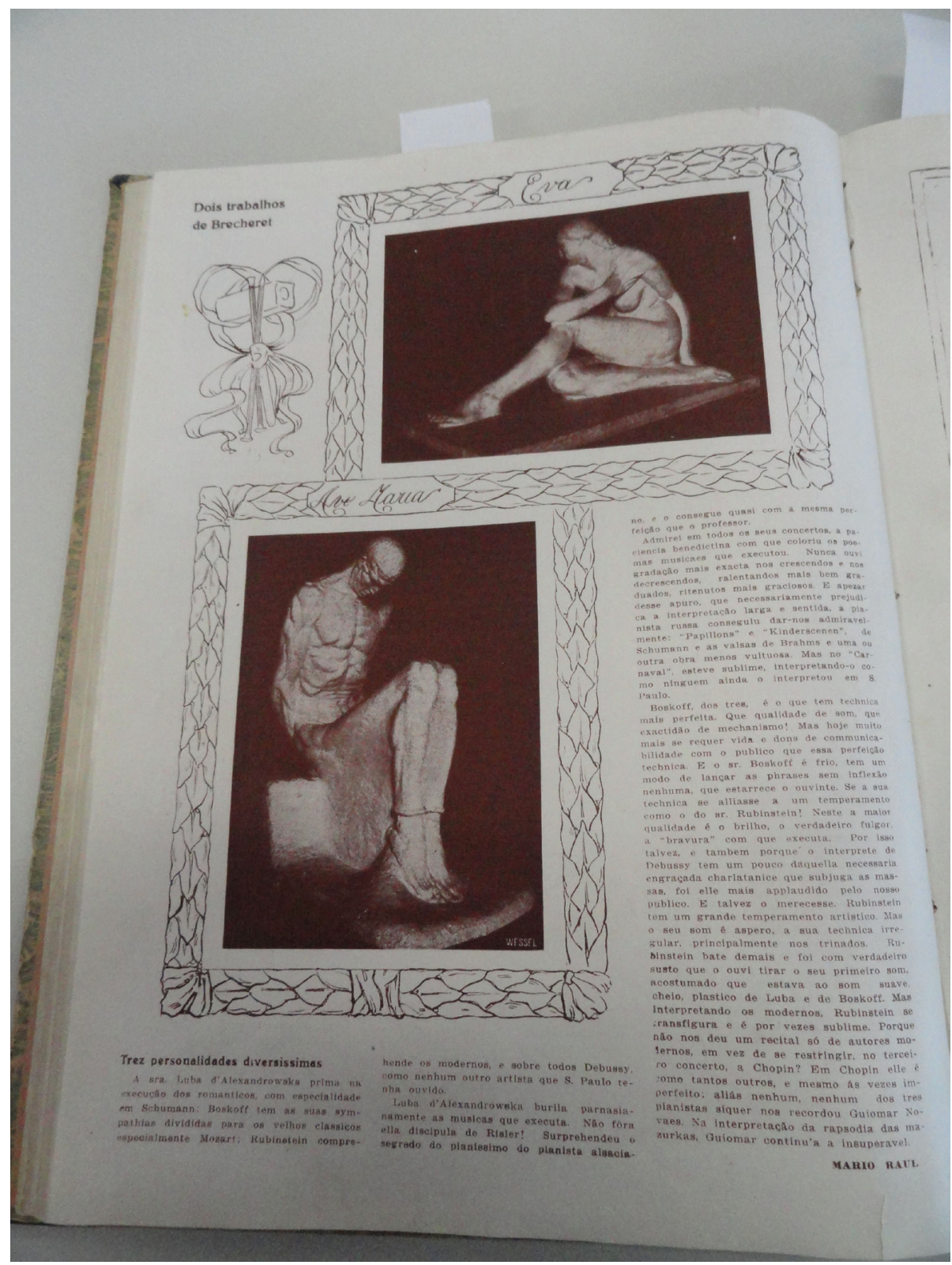

Eva e Ave Maria - esculturas de Brecheret citadas no artigo de Mário de Andrade. 


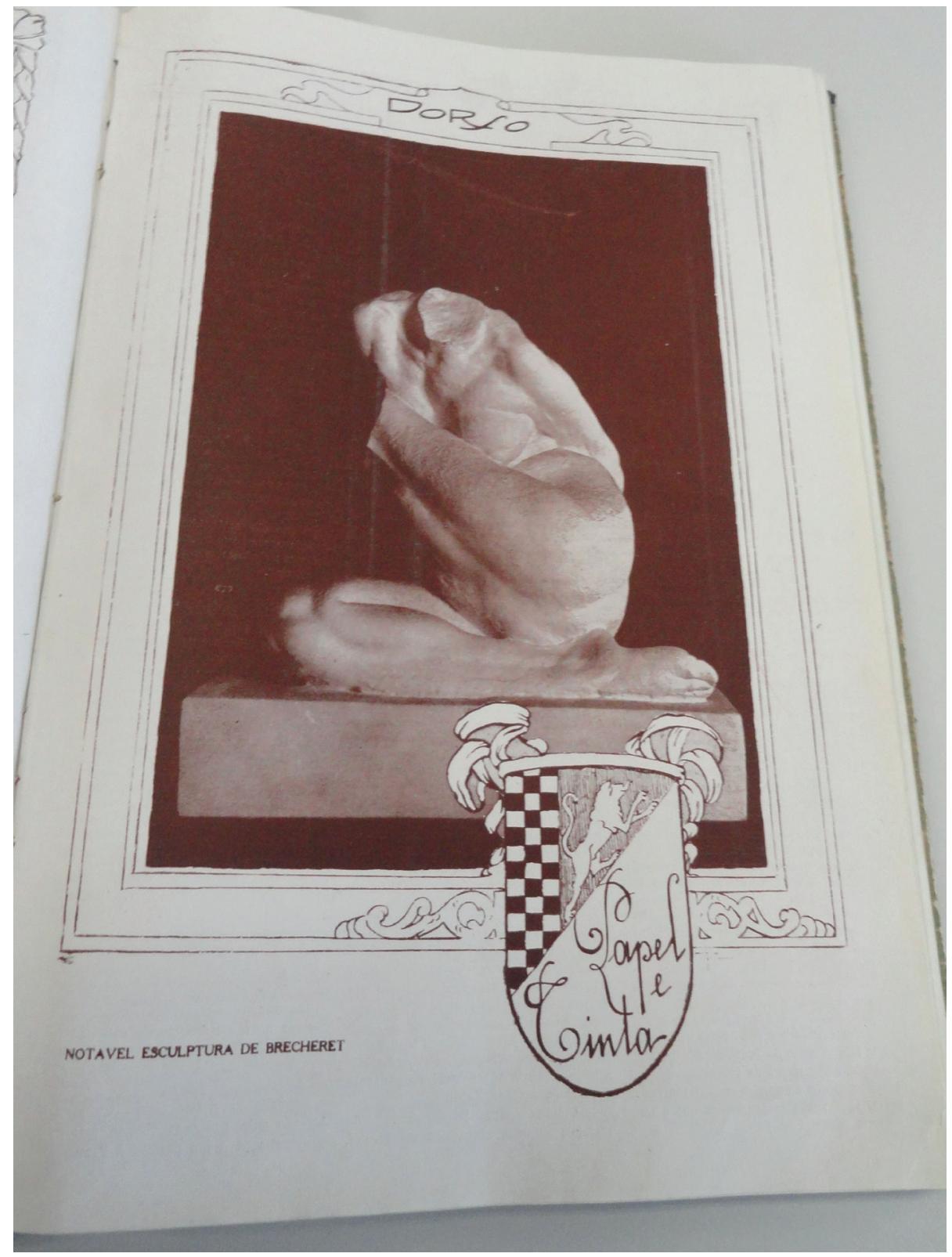

Dorso - escultura de Brecheret citada no artigo de Mário de Andrade. 


\section{COM O ESCULTOR BRECHERET EM PAPEL E TINTA}

Em estreita conexão com o dossiê jornalístico nos álbuns, vêm os textos de Mário de Andrade crítico de arte, em Papel e Tinta. Graficamente muito bem elaborada, a revista nasce em maio de 1920 e dura até 1921. Congrega, em São Paulo, escritores e artistas plásticos ávidos de contemporaneidade; confraterniza com a Revista do Brasil e se julga também um periódico do Rio de Janeiro, capital da República. É regida pela Sociedade Editora Non Ducor, Duco, ou seja, amigos reunidos que escrevem, ilustram, selecionam quadros para reproduzir, cavam anunciantes. Não acusa corpo editorial e tem em Menotti del Picchia a principal alavanca. Na literatura, conta com Menotti, Oswald de Andrade, Mário, Guilherme de Almeida, que se modernizam, apesar do estilo minado por fortes marcas do passado. Nomes consagrados como Gonzaga Duque, Cláudio de Souza e João do Norte (Gustavo Barroso) granjeiam leitores. A revista, que imprime pinturas acadêmicas e se expande no art nouveau, no art déco, elege a escultura de Brecheret seu "estandarte" modernista. A ele confia a criação do logotipo. Em 1920, reassegura os ideais de transformação na presença constante de fotografias de obras do criador de Eva. Essas imagens convivem com as ilustrações de Paim que enobrecem as páginas, sem, contudo, ultrapassar o art nouveau.

No no 2, em junho de 1920, o artigo de Ivan, "Victor Brecheret", na seção "Ars", analisa esculturas; nas páginas seguintes, veem-se Eva, Ave Maria e Dorso; não há menção ao Monumento das bandeiras ${ }^{6}$. Ivan reivindica o Pensionato do Estado, isto é, aperfeiçoamento em Paris para o artista que insere na "ronda dos inovadores" - Mestrovic, Bourdelle, Carl Millès e outros. Segundo Mário da Silva Brito, o pseudônimo Ivan encobre Oswald de Andrade (BRITO, 1958, p. 94) ${ }^{7}$. Prestando-se atenção no estilo, no uso da língua portuguesa do Brasil, na epígrafe colhida em Frei Luís de Sousa, no conhecimento sólido de História da Arte, no nome Michelangelo abrasileirado para Miguel Anjo e, principalmente, na religiosidade, outra autoria se esgueira - Mário de Andrade.

Enquanto o articulista escolhe em Frei Luís de Sousa a epígrafe "A natureza nunca foi avara em criar grandes talentos, mas falta, muitas vezes, dar ao mundo quem os entenda”, para aludir à difícil recepção da arte de Brecheret, o poeta paulistano presenteia, com outro excerto

6. O presente artigo adota o título primeiro conferido: Monumento das bandeiras.

7. É interessante pensar que o pseudônimo Ivan pode talvez derivar do nome de batismo do grande escultor moderno Mestrovic, com quem Brecheret era comparado. 
do grande quinhentista português, seu próprio poema “Inspiração”. Em Pauliceia desvairada, livro marco do modernismo brasileiro em 1922, escrito desde 1920, a invocação da cidade musa e dama do trovador do século XX - "São Paulo! Comoção de minha vida..." - é prenunciada pela epígrafe que crisma a oscilação/contradição do clima paulistano como metáfora dos paradoxos e contradições da cidade microcosmo: "Onde até na força do verão havia tempestades de ventos e frios de crudelíssimo inverno".

A presença de Frei Luís de Sousa corresponde, no modernismo, à valorização do passado como "lição para se meditar, não para reproduzir", conforme o "Prefácio interessantíssimo" de Pauliceia desvairada, prefácio com fôlego de manifesto.

Em Ivan, as manifestações de religiosidade, cuidadosamente dispostas no texto, podem ser aproximadas aos versos de "Religião" que exclamam, em Pauliceia desvairada: "Deus! creio em Ti! Creio na tua Bíblia! // Não que a explicasse eu mesmo, / porque a recebi das mãos dos que viveram as iluminações!" e condenam a hipocrisia na prática religiosa católica (ANDRADE, 2013f). No artigo, em 1920, Brecheret é assim anunciado: "[...] voltou há alguns meses da Itália onde foi estudar o catecismo da arte”, e, logo depois, a análise de um trabalho dele, Cabeça de Cristo, no viés da imaginária religiosa na História da Arte, culmina num ato de fé:

Naquela imobilidade pensativa, naqueles lábios sobrenaturais, no ríctus da boca, nas tranças arcaicas, o artista conseguiu prender, de modo genial, as tragédias, as esperanças, o sacrifício divino - todo um calvário de imolações formidandas. O Cristo de Brecheret é Deus!

Oswald de Andrade era também católico, pode-se retrucar. Todavia, até aquele ano de 1920, a religião nada merecera em seus escritos. Diferentemente, Mário de Andrade, em 1917, na expressão do eu lírico no seu livro Há uma gota de sangue em cada poema e nos artiguetes na coluna "Eclesiastes" da revista Miscelânea, ou no "Conto de Natal", datado de 1918, frisa seu catolicismo norteado pela noção de Charitas ${ }^{8}$. E declara, no "Prefácio interessantíssimo" de Pauliceia desvairada: "Quem não souber rezar, não leia / 'Religião”'.

Quanto ao apelativo Michelangelo, traduzido para Miguel Anjo, vale recordar o nome de batismo do amigo Oswald de Andrade abrasileirado para Oswaldo, na crônica "De São Paulo", em março de 1921, e os de Bach,

\footnotetext{
8. O conto sai em 1926, no livro Primeiro andar.
} 
Jean Epstein e Émile Bayard, grafados como João Sebastião, João e Emílio no "Prefácio interessantíssimo".

Finalmente, para desvelar Mário de Andrade no pseudônimo Ivan, basta dizer que era ele o proprietário da peça elogiada na Papel e Tinta, como se arremata em sua conferência de 1942, "O movimento modernista". Nesse lúcido balanço das conquistas e dos percalços da renovação efetuada, está o reconhecimento da arte de Brecheret como o "gatilho" que fizera "Pauliceia desvairada estourar". O depoimento restitui (ou encena) esta história: o poeta conseguira, a duras penas em suas finanças, que Brecheret passasse para o bronze a Cabeça de Cristo, cuja versão em gesso o empolgara. Modernista eufórico, ao se pavonear com a escultura perante a família, frustrara-se com a recepção e, indignado, pudera, finalmente, pôr no papel os poemas modernos que tencionava compor sobre sua cidade, e achar o título para o livro Pauliceia desvairada.

Estas minhas cogitações de 2003 (LOPEZ, 2003) ${ }^{9}$ patentearam-se, em 2012, na ficha "Mário de Andrade", descoberta por minha colega Tatiana Longo Figueiredo no arquivo do escritor (LOPEZ, 2012, p. 29-38) ${ }^{10}$. A ficha arrola todos os títulos por ele publicados nas revistas Klaxon e Papel e Tinta, mas não aponta pseudônimos e assinaturas ${ }^{11}$. Assim, ao ligar "Brecheret e pianistas" ao $\mathrm{n}^{\circ} 2$ de Papel e Tinta, mostra-se como Ivan e como o Mário Raul que, em "Três personalidades diversíssimas", ocupa-se de recitais ${ }^{12}$.

Na Papel e Tinta, este jornalista realmente se multiplica. Chega aos leitores em crônicas, contos, esquetes, crítica de artes plásticas, cinema, literatura e música; é Ivan, Mario Raul, Pedro de Alencar, Antonio

9. Minha primeira abordagem pública da série "De São Paulo" deu-se no artigo "Preludes to Modernism in Brazil" (LOPES, 2002).

10. Tatiana Longo dos Santos, que é bolsista de pós-doutoramento no IEB-USP, localizou a informação no decorrer da pesquisa em que ela recenseia e analisa a presença da literatura brasileira no Fichário analítico de Mário de Andrade, uma espécie de enciclopédia constituída pelo escritor para uso próprio. V. ficha 2300, fólio 3739 do manuscrito. A ficha está transcrita em seu relatório à FAPESP (São Paulo, setembro de 2012).

11. Nas revistas citadas, a assinatura varia: Mário de Andrade, M. de A., Mário Raul. Os pseudônimos também. A ficha inclui ainda os poemas "Nature" e "Paysage", traduzidos por Sérgio Millliet e publicados na revista Het Overzicht, ${ }^{\circ} 20$ (Amsterdam, janeiro de 1924, p. 130-131); estão no v. 2 da edição das Poesias completas de Mário de Andrade (Nota 9).

12. Mário focaliza o estilo de Luba d' Alexandrowa, Boskoff e Rubinstein, pianistas. 
Cabral, Sacy Pererể ${ }^{13}$ Mário de Andrade e Morais Andrade; às vezes nem assina, a autoria perceptível no estilo ou em menções autobiográficas. O ônus da transição atinge sobretudo crônicas e artigos, nos quais as ideias avançadas, a adoção do português falado no país, os neologismos fundem-se a construções "belle époque" ou a preciosismos francamente parnasianos.

\section{MODERNISMO PARA UM CENTENÁRIO}

Victor Brecheret serve, por certo, ao ideário dos modernistas desde o impacto que neles causara a atualidade de sua escultura, como atesta Menotti del Picchia cronista, no Correio Paulistano de 15 de janeiro de 1920. No mesmo momento, esses intelectuais paulistanos, que aplaudiam a força renovadora de sua arte, resolvem tomá-la como significado maior da comemoração do Centenário da Independência, em 1922. Almejam nova dimensão para o tema das bandeiras de São Paulo, já levantado no Museu do Ipiranga, em 1920, numa conferência do diretor da instituição, Afonso de Taunay, que encomendara a Luigi Brizzolara, conceituado artista acadêmico, duas estátuas de bandeirantes e uma alegoria do Tietê. Taunay é amigo dos moços modernistas em cujo imaginário mora "O caçador de esmeraldas", célebre poema de Bilac. Urgia, naquela hora, sublinhar a importância de São Paulo como berço da independência e da nacionalidade. E a revista Papel e Tinta, na qual os jovens se desdobram em pseudônimos para dar a impressão de um número maior de colaboradores, absorve o tema lavrado por Bilac e Taunay. Incumbem Brecheret de criar uma interpretação das expedições dos bandeirantes, batem-se na imprensa para que a maquete se torne pedra e bronze, até o Centenário. Empenhados em uma arte de cunho nacional, dialogam com ele e ingressam na criação do Monumento das bandeiras, um projeto despojado, revolucionário em termos de Brasil. Em julho de 1920, o terceiro número de Papel e Tinta, na seção "Ars", a maquete fotografada ratifica o memorial descritivo "O Monumento", assinado por Victor Brecheret, texto que não hesita em transcrever Taunay, um aliado na correlação de forças:

13. O desvendamento do pseudônimo Antônio Cabral prende-se a menção à Barra Funda, no texto, e o de Sacy Pererê está, na letra de Mário, em sua coleção de Papel e Tinta. 
62 - Remate de Males 33.1-2
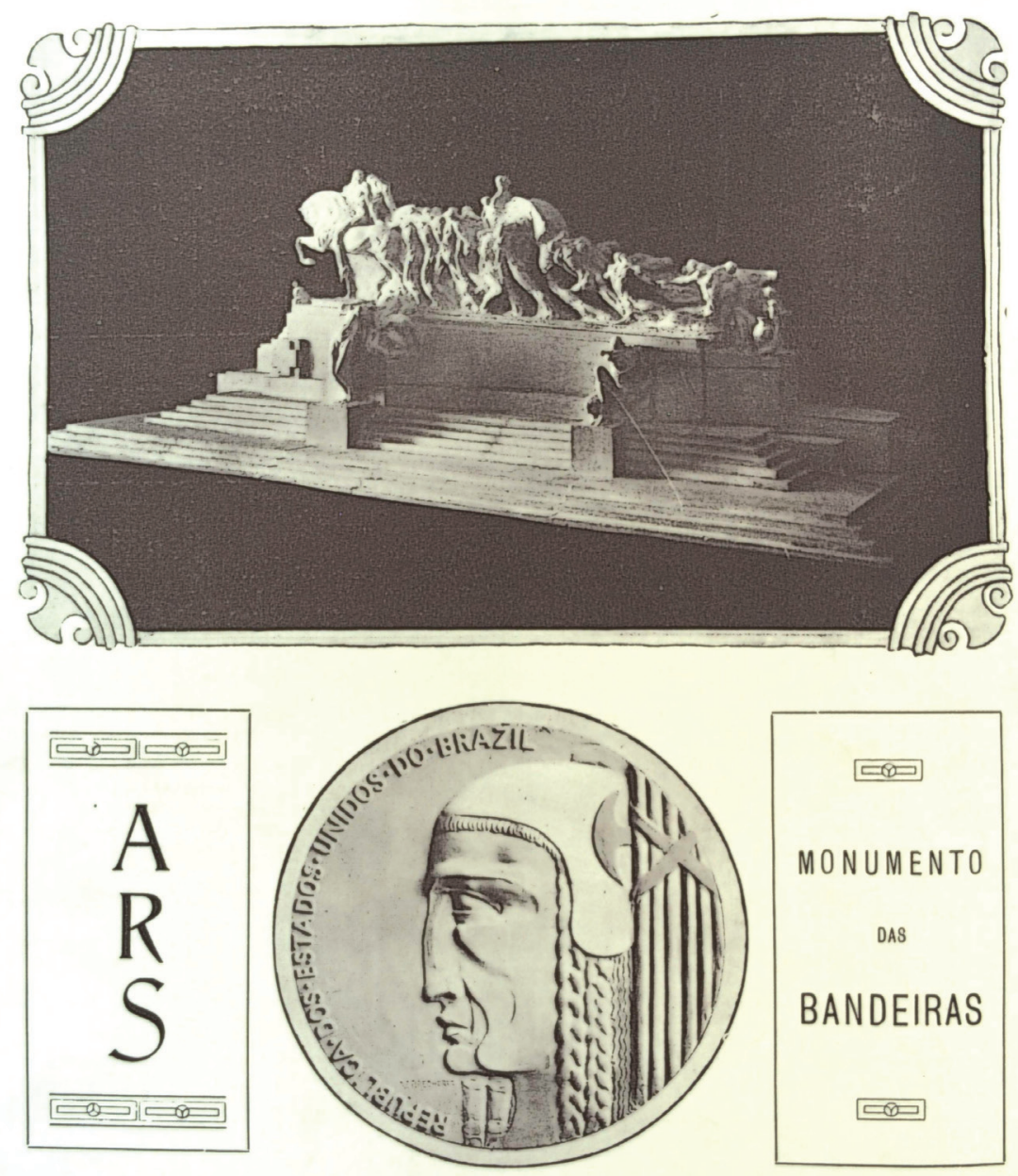

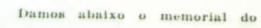
notavel esculptor Brecheret, refe. rente tho beu projecto do monu. mento ä handelrats. verandion

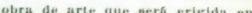
nario, oflerecida a Patria peloo pariliatan

\section{o MoxuMExTo}

A epopéa das."Bandeiras" é de per si uma id́́a esculptorea, tal a impressão tacanha lendarla que suggere o cyclop de feito dos paulistas.

Cousiderado em sl a cyelo dus -Eutradus", o trabalko desses titáes du terra e desses Argonautas dos rlos, como movimentos successivos de uma mesma forca continua, a ldéa de um grande bloco se impore a concepea a do artiata o qual não về na traglea e f́lca historla do des-

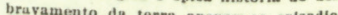
- apenas os eplsodio to da Cagada das Esmeraldas, a Cavalga-

Monumento das Bandeiras de Brecheret. 
Na parte posterior colocamos a Ânfora que conterá água do Tietê, sagrado pela glória das "monções". Sugeriu-nos essa ideia a conferência do sr. Afonso de Taunay neste tópico:

“Ao padrão nacional evocador da glória das 'Bandeiras' virá trazer a presença da ânfora da água do Tietê a nota do mais poderoso e poético simbolismo".

Todavia, quando se conhece o português macarrônico dos bilhetes e cartas do Rodin brasileiro, é inevitável a pergunta: quem realmente escreveu o memorial? Quem, para publicar, demandava a mão do gato? Mário da Silva Brito elege Menotti (BRITO, 1958, p. 106). Da minha parte, penso em Mário de Andrade, como o poeta incógnito, citado no projeto, cujas ideias coincidem com as que ali estão e cuja caneta teria dado forma à contribuição de vários. Aliás, desde janeiro de 1920, ele aparece como crítico de arte na Revista do Brasil (ANDRADE, 1920a) ${ }^{14}$.

Esse liame traz à cena, de novo, o álbum preto onde se aloja o soneto "Anhangabahú", cuja primeira estrofe possui a mais antiga referência da poesia andradiana ao bandeirismo paulista. Impresso em azul, sem indicação de periódico ou data, o soneto conjuga o pseudônimo Don José à assinatura em autógrafo "Mario Moraes Andrade". A cor azul e a vinheta indicam retalho de A Cigarra, revista semanal paulistana; a data retorna com Ricardo Souza de Carvalho, em "Jardins modernistas". Estudando os parques e jardins nascidos para ornamentar as cidades, o ensaísta levanta dados sobre o concurso n'A Cigarra que, em julho de 1917, estipulou um prêmio de 500 mil-réis ao soneto que tirasse do esquecimento o rio histórico já canalizado sob um parque de imitação europeia. O estreante Mário Sobral, cujo livro Há uma gota de sangue em cada poema vinha recebendo elogios da $\mathrm{crí}^{1} \mathrm{ca}^{15}$, entrou no páreo que teve como vencedor Ribeiro Couto. Obteve menção honrosa e, em 12 de julho de 1918, a revista trouxe o seu "Anhangabahú" (CARVALHO, 200o, p. 195-214 $)^{16}$. Soneto quase desconhecido, cumpre transcrevê-lo na íntegra, diplomaticamente, para transmitir um pouco do sabor do passado:

14. Série assinada "M. Moraes de Andrade".

15. Ver VEIGA MIRANDA. Há uma gota de sangue em cada poema. Pocai \& C., 1917. Jornal do Comércio. São Paulo, 15 de agosto, 1917. Série Matéria extraída de periódicos; Arquivo Mário de Andrade. Indicação de periódico e de data em Nota MA, autógrafo a tinta preta. A série guarda outras críticas elogiosas ao livro.

16. Sigo as datas colhidas pelo pesquisador em A Cigarra, São Paulo: no no 70, em 11 de julho de 1917, o lançamento do concurso; no no 95, em 12 de julho 1918, publicação do soneto "Anhangabahú". 
Anhangabahú

Fino, límpido rio, que assististe, em épocas passadas, nas primeiras horas do dia, a despedida triste das heróicas monções e das bandeiras;

meu Anhangabahú das lavadeiras, nem o teu leito ressequido existe! Que é de ti, afinal? Onde te esgueiras? Para que vargens novas te partiste?

Sepultaram-te os filhos dos teus filhos; e ergueram sobre tua sepultura novos padrões de glórias e de brilhos...

mas dum exílio nãote amarga a idea: levas, feliz, a tua vida obscura no proprio coração da Paulicéa! ${ }^{17}$

No memorial descritivo "assinado" pelo escultor, Taunay e Bilac mostram-se, de modo indelével, como matrizes interdisciplinares do tema desenvolvido no monumento e o redator oculto dissemina pistas de um texto que estaria brotando na área literária. Ao término da descrição do Grupo Central, parece não resistir ao entusiasmo e cita versos sem identificar a fonte, versos inexistentes de toda a obra que Menotti publicou:

O Grupo carrega o "Arado", símbolo da obra humana, da fertilidade consciente, que vai substituir a feracidade selvagem e tropical do sertão americano. Na cauda da expedição, com o esporão agudo voltado para o alto, os heróis arrastam a canoa das "monções", destinada a singrar o Tietê histórico que a fugir, pouco a pouco se perde no majestoso, vago, infinito sertão... ${ }^{18}$

Em seguida, mais um verso sem autoria declinada liga-se ao memorial, quando dos esclarecimentos sobre os Grupos Laterais; corrobora a alegoria da Terra Brasileira. Eis o instante no qual "essa figura enigmática que pompeia na frente do monumento” ganha força de atração:

Ela, como a Mãe-d'Água os arrastou, pela tentação, da morte à imortalidade, da conquista à chacina, da provação à glória. Foi a Terra para eles, como cantou o Poeta, mãe piedosa e pura, mas cruel e implacável assassina.

17. O poema foi incluído na parte "Poemas publicados por Mário de Andrade em jornais e revistas", no v. 2 da edição citada de Poesias completas.

18. Mário da Silva Brito transcreve o memorial em sua História do modernismo brasileiro: antecedentes da Semana de Arte Moderna (1958, p. 104-106). 
No paradoxo, a consciência das contradições, ou melhor, da complexidade do feito, anima a exaltação das bandeiras, cujo sacrifício e cuja glória, para o "artista", concentram-se simbolicamente na ânfora que recolhe a água sagrada do Tietê, fecho do monumento e uma espécie de cálice da comunhão paulista, "a nota mais poderosa de poético simbolismo", conforme o trecho de Taunay evocado. A metáfora da ânfora, ao que se pode julgar, demarca, no excerto da conferência de Taunay oferecido pelo memorial da maquete, a nascente de uma obsessão magna da poesia mariodeandradina: o Tietê, signo da cidade de acertos e descaminhos, da São Paulo microcosmo. Fundido ao eu lírico no passar dos anos, no derradeiro poema da vida de Mário de Andrade, "A meditação sobre o Tietê", o rio abrigará a compreensão da inelutável dor humana ${ }^{19}$.

O poeta incógnito, a partir da inclusão de versos seus no memorial, abona, também parceiro de quem analisa a maquete e também criador virtual do Monumento, a conferência de Taunay como matriz da escultura, ao mesmo tempo em que recria o périplo dos bandeirantes, nos fragmentos do poema ali aproveitados. Desse modo, é possível compreender os versos que ilustram o memorial de 1920 como vestígios de uma redação antiga e desaparecida do poema "Tietê", diferente daquela que foi parar no livro Pauliceia desvairada, em 1922. Versão para a qual, mudado o rio, teriam sido trasladados e refeitos os bucólicos e parnasianos versos de "Anhangabaú", acima transcritos, uma vez que o poema modernista de título análogo - não mais soneto - , publicado na mesma obra, contempla com ironia o parque ornamentado para o Centenário, com as estátuas de bronze do cinzel acadêmico de Luigi Brizzolara. E nesse caminhar baudelairiano do poeta pela metrópole, organizando, em 1922, uma sucessão dos quadros paulistanos, o rio cantado em 1919 por Don José ressurge na valorização do novo, por meio da colagem (entre aspas) dos versos de Manuel Bandeira, superando a nostalgia do passado:

Estes meus parques do Anhangabaú ou de Paris, onde as tuas águas, onde as mágoas dos teus sapos?

"Meu pai foi rei!

-Foi. - Não foi. -Foi. - Não foi.”

Onde as tuas bananeiras?

Onde o teu rio frio encanecido pelos nevoeiros,

Contando histórias aos sacis?... (ANDRADE, 2013a, v. 12-18)

19. “A meditação sobre o Tietê" recaptura as obsessões do poeta no decorrer de toda a sua obra; foi concluído por Mário em 12 de fevereiro de 1945, 13 dias antes de sua morte (In: "Lira paulistana"; In: Poesias completas, v.1; ed. cit.). 
O confronto do memorial descritivo em Papel e Tinta com o poema modernista "Tietê" acusa, neste, o abandono quase completo do tom épico que impregna o discurso do redator e os versos por ele escolhidos. Em "Tietê", por meio da polifonia poética, veículo da simultaneidade produzida pelo conjunto de versos harmônicos e melódicos e da sucessão de quatro frases telegráficas (v. 12-13), o eu lírico se instala no presente para instituir, na ironia moderna, a visão nostálgica e paradoxalmente desmistificada das bandeiras paulistas. Na esteira do futurismo, a metrópole cosmopolita do século XX predomina e, na literatura de circunstância postulada por Mário de Andrade e por ele descoberta no expressionismo alemão, o rio faz o prazer do esportista e reflete os cartazes do comércio. A história e o imaginário se condensam na dimensão estética atual - a representação concretizada por Brecheret. Só a arte de Brecheret conserva o sentido épico que a literatura imprimira às bandeiras e monções, sentido minado pela dúvida, todavia. Ou melhor, a arte se reveste da visão dialética das bandeiras que o poeta possui, dentro da qual preza a expansão do território sabendo o preço pago pelo homem, o custo enfim da dimensão épica, esgarçada, no século XX, no enunciado da ficção, na voz do povo - "Era uma vez um rio...”. Moderno, o poema "Tietê" vive com ironia o hoje prosaico, sem a glória traduzida em ambição e conquista. A escultura e a história veem-se interpretadas na poesia moderna:

Era uma vez um rio...

Porém os Borba-Gatos dos ultra-nacionais esperiamente!

Havia nas manhãs cheias de Sol do entusiasmo as monções da ambição...

E as gigânteas vitórias!

As embarcações singravam rumo ao abismal Descaminho...

Arroubos... Lutas... Setas.... Cantigas... Povoar!...

Ritmos de Brecheret!... E a santificação da morte!

Foram-se os ouros!... E o hoje das turmalinas!...

— Nadador! Vamos partir pela via dum Mato-Grosso?

— Io! Mai!... (Mais dez braçadas.

Quina Migone. Hat Stores. Meia de seda.)

Vado a pranzare com la Ruth (ANDRADE, 2013g).

Aplicado leitor da História da Arte e de Estética, como sua biblioteca bem indicia, Mário, amparando-se no primitivismo preconizado pelas vanguardas europeias, conclui a respeito do Monumento das bandeiras de Brecheret: "Não é um espelho, é uma fonte viva de criação, impressionante 
na coerência com que junta à estilização eloquente do símbolo a sadia inocência dos primitivos".

\section{O MODERNISMO E UMA REVISTA ECLÉTICA}

A revista mensal carioca Illustração Brazileira, com assinantes além do eixo Rio-São Paulo, dilata a difusão do modernismo paulistano. Propriedade da Sociedade Anônima O Malho, reaparece em setembro de 1920, seu oitavo ano, depois de interrupção em fevereiro de 1915, causada pela guerra mundial; restringe-se a um Brasil urbano e ignora contradições sociais. Tem como Diretor-Secretário Álvaro Moreira, que, na esfera do modernismo, fará o Teatro de Brinquedo, em 1927. Um exame das páginas do periódico impresso com apuro em papel cuchê detecta, em 1920 e 1921, variedade de seções, uso farto da fotografia, ilustração requintada, muitos anúncios, alguns de página inteira, como os da revista infantil $O$ Tico-Tico e dos Cigarros La Reina, sem nicotina, apregoados por rotunda beldade. O progresso no século XX limita-se a gente na praia, de touca e recatados maiôs, garotas em vestidos de cassa que praticam tiro ao alvo; à façanha do aviador Edu Chaves, aos automóveis Ford e Studebacker, ou a acontecimentos igualmente amenos. Pedro II, o imperador deposto, o rei Alberto da Bélgica, rainhas e generais fotografados firmam notícias; poses em estúdio de senhorinhas e senhoras muito chiques, de crianças bem nascidas afiançam a Illustração Brazileira na fatia da sociedade à qual se dirige; propagam o brilho das festas da alta sociedade e dão azo ao leitor "voyeur". Enquanto mensário de arte e cultura, é eclética e namora timidamente o novo século. Na literatura, mescla parnasianos e simbolistas. Nos dois anos que focalizo, Álvaro Moreira, dentre os escritores do Rio que ali comparecem, é quem arrisca mudanças. Quanto à música e às artes plásticas, uma partitura de Gallet coexiste com fotos de divas da ópera italiana e alemã; pinturas de artistas acadêmicos como Lucílio de Albuquerque, Rodolfo Amoedo ou Navarro da Costa, em página inteira, intercalam-se ao art nouveau dos magníficos desenhos de Chin; em maio de 1921, nota-se um desenho de Di Cavalcanti. Para a reprodução de uma obra de Rego Monteiro, o espaço é diminuto.

\section{NO RIO, COM MÁRIO E BRECHERET}

Em setembro de 1921, o número de relançamento da Illustração Brazileira estampa a fotografia da maquete do Monumento das bandeiras 
de Brecheret, divulgada na Papel e Tinta de julho, 1920, agora em viragem azul $^{20}$. Trecho do memorial descritivo, em nova versão e sem assinatura, serve-lhe de legenda:

O grupo central, movido ritmicamente, de maneira a sugerir uma "entrada". Os paulistas, guiados por Paes Leme, Antônio Pires, Borba Gato, avançam para o sertão misterioso... ${ }^{21}$

A inclusão dessa matéria reflete, na Capital Federal, o alargamento da campanha de 1920, no Correio Paulistano, nas páginas da Papel e Tinta, da Revista do Brasil, na pena de Menotti, Oswald de Andrade, Di Cavalcanti, Lobato; conquistara até o conservador Raul Polilo, como historia Mário da Silva Brito (1958) 22 .

Os vanguardistas da Pauliceia consideram o Monumento das bandeiras não apenas representação do desbravamento heroico no passado, mas sinônimo de uma cidade e de um estado comprometidos com a modernidade, prontos para proclamar essa sintonia nacionalmente, no centenário da Independência. Querem que a maquete seja concretizada para transmitir a mensagem da renovação em uma obra pública, como ocorria na Europa. Anseiam contestar, dessa maneira, o conservadorismo dominante na sociedade paulistana que convalidara oficialmente a passagem para o bronze do Monumento à Independência assinado por Ettore Ximenes, vencedor do concurso de 1919, o qual atraíra apenas escultores acadêmicos. Nossos modernistas tinham percorrido certamente, em 1919, embora não a evoquem, a exposição da pintura de impressionistas e de esculturas de Bourdelle, Rodin e Henri Laurens que Paulo Prado, Freitas Vale e o cônsul da França promoveram no saguão do Teatro Municipal (CAMARGOS, 2001, p. 178).

São Paulo modernista lega a Mário de Andrade a responsabilidade de aclamar nacionalmente o valor de Brecheret; não perde a esperança de ver o Monumento das bandeiras desafiando, na cidade, a obra de Ximenes; é fundamental obter um financiamento na burguesia. $\mathrm{O}$ cronista correspondente "Mário de Andrade" inicia, como já se sabe, em novembro de 1920, a série "De São Paulo", que vai até maio de 1921, na

20. Página não citada, devido à ausência de numeração, na revista.

21. Em Papel e Tinta, na descrição do Grupo Central, se lê: "O grupo monumental, que é a coluna dorsal do monumento, foi movido ritmicamente de maneira a sugerir uma 'entrada'. A grande massa processional, guiada pelos 'Gênios' - os Paes Leme, os Antônio Pires, os Borba Gato, avança para o sertão desconhecido”.

22. O historiador rastreou, nos jornais paulistanos de 1920-1921, todos os títulos que, para ele, apresentassem o desenrolar da luta modernista. 
Illustração Brazileira. Recuperada no álbum de seu autor e na biblioteca de Yan de Almeida Prado no acervo do IEB-USP, contribui vivamente para documentar a implantação do movimento.

Extensas, as cinco crônicas combinam o relato irônico com a análise; noticiam e narram a História; traduzem "propósitos" - enaltecer a cidade moderna, pregar a renovação nas artes e na literatura. Com irreverência, humor, filtram nas impressões fatos na cidade, e explicitam um compromisso.

Em novembro de 1920, a primeira "De São Paulo" está no no 3, ano 8, da Illustração Brazileira, enfeitada com vinheta e capitular "belle époque", fixando o padrão ornamental da série. Vem sem medo de definir a cidade como "hermafrodita". Os acontecimentos mostram-se como uma grande soma de sensações e impressões, tentando passar, por meio da enumeração, recurso predominante, o dinamismo urbano que fascina o cronista. São textos de um apaixonado que não ignora os problemas de ordem cultural e que, no correr da série, aguçará sua crítica, sem, contudo, buscar as contradições sociais, como o poeta de Pauliceia desvairada, nessa altura imerso na criação do livro de 1922. Por enquanto, o cronista descobre a intensidade semântica do adjetivo "desvairado", na captação da pluralidade de sensações, nas sinestesias. Exprime, na Illustração, seu deslumbramento com o século XX, com a metrópole que lhe coube, modernolatria cheia do orgulho paulista, dissociada da preocupação com o sofrimento humano nas cidades modernas, linha de força na poesia de Verhaeren e no expressionismo alemão, leituras que acordam, paralelamente, a consciência do poeta. O primeiro texto "De São Paulo” reparte-se entre a contemplação amorosa, lírica, e a análise que se alimenta do memorial de Brecheret:

São Paulo toda se agita com a aproximação do Centenário. Germinam monumentos numa floração de gestos heróicos; as alamedas riscam o solo em largas toalhas verdes e os jardins se congregam em formosos jogos florais de poesia e perfume. São Paulo se arreia de graças. São Paulo quer tornar-se bela e apreciada. Finalmente a cidade espertou num desejo de agradar. E era preciso que assim fosse.

A urbe de Amador Bueno é agressiva e misteriosa como seus heróis; suas belezas recônditas; raro o estrangeiro que alcança levantar um pouco o pesado manto de segredo em que se embuça. Num orgulho tradicional ela sempre se guardou rudemente, medievalmente, como certas igrejas de Itália que, sob uma feição esquipática e bisonha, ocultam a severa doçura dum Cimabue, dum Piero della Francesca ou os arco-íris dos mosaicos bizantinos. E no entanto ela é curiosa, viva, singular; e para o paulistano inveterado, que ama e contempla, tem sugestões tão inéditas como os versos de Mallarmé. Dizem-na fria... Dizem-na tristonha, escura... Mas no momento em que escrevo, novembro anda lá fora, desvairado de odores e colorações. Eu sei 


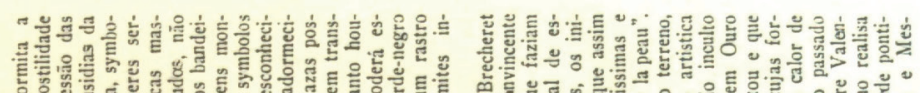

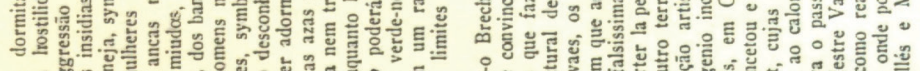

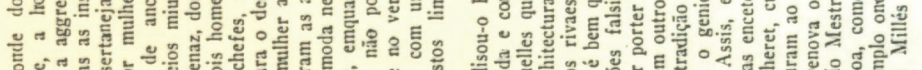

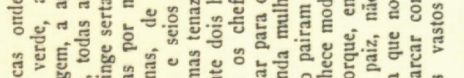

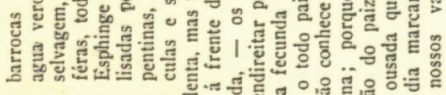

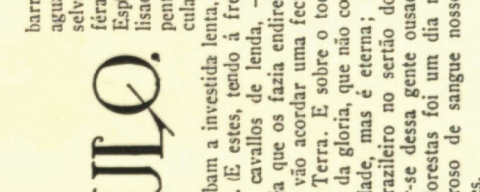

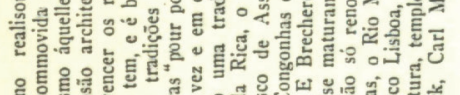

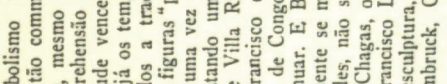

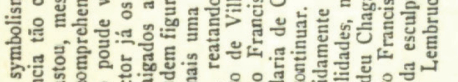

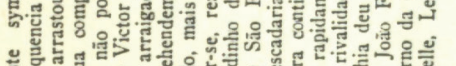

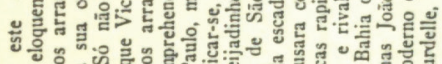

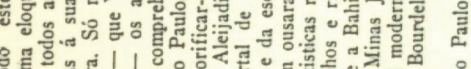
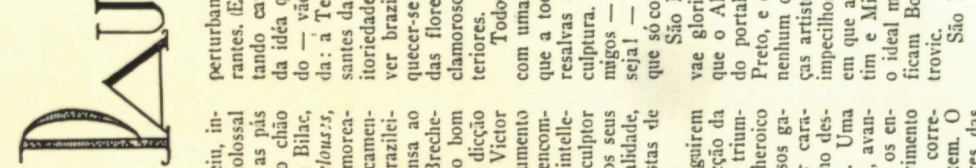

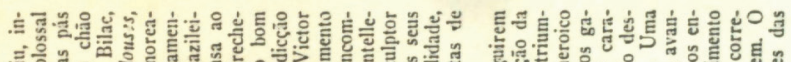

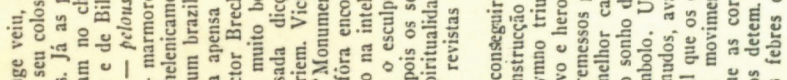

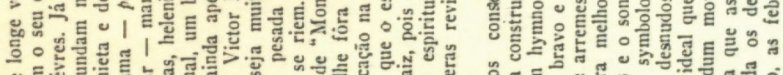

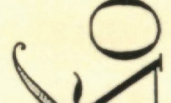

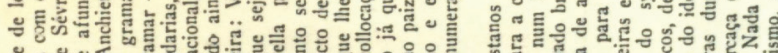

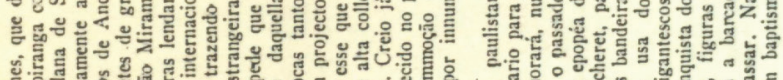

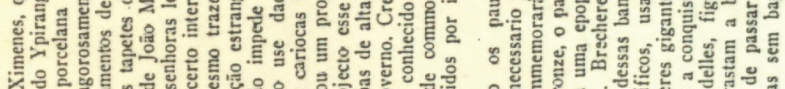

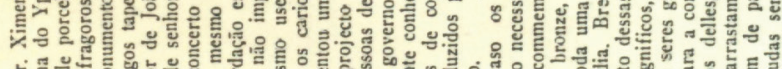

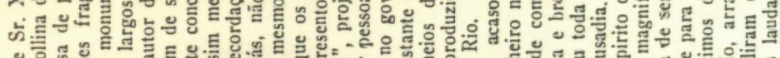

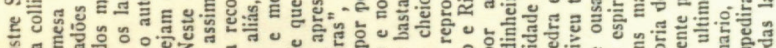

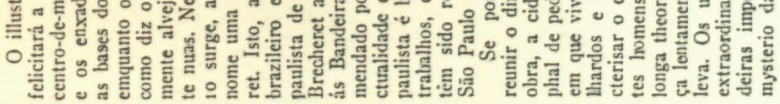

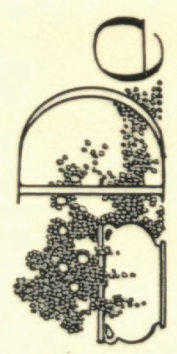

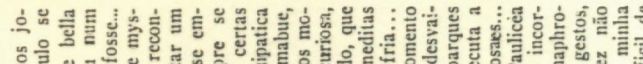

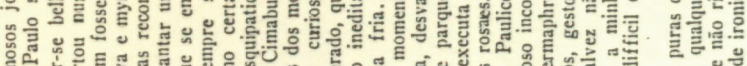

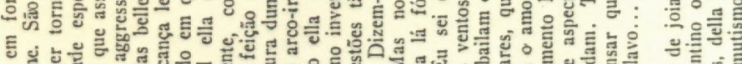

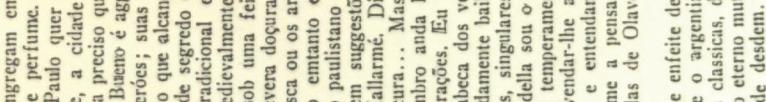

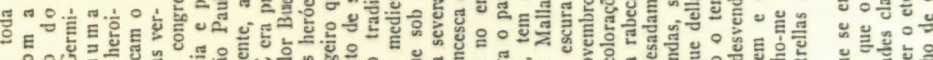

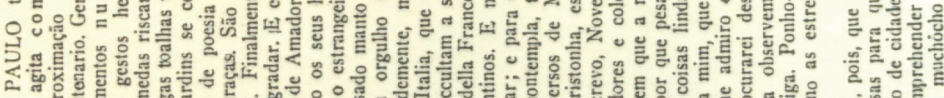

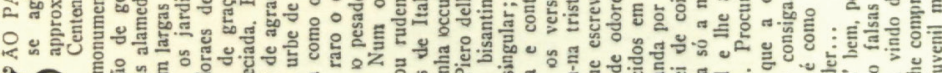
62 
de parques esquecidos em que a rabeca dos ventos executa a sarabanda por que pesadamente bailam os rosais... Eu sei de coisas lindas, singulares, que a Pauliceia mostra só a mim, que dela sou o amoroso incorrigível e lhe admiro o temperamento hermafrodita... Procurarei desvendar-lhe aspectos, gestos, para que a observem e entendam. Talvez não muito consiga. Ponho-me a pensar que a minha terra é como as estrelas de Olavo... difícil de entender...

Culto, o cronista refere-se à arte antiga italiana como se a tivesse visitado, ele que não se aventurara além de Santos, Itanhaém, das cidades históricas mineiras e de outras, bem poucas, no interior paulista. Essa marca de viajante ao redor de suas leituras enche de vivacidade o "testemunho"23. Entre penumbrista que brinca com o parnasianismo e modernista que se exercita nas frases soltas, vibrando ao sabor das reticências, musicalmente, avizinhando-se da poética de Pauliceia desvairada, construída no "Prefácio interessantíssimo" no final do ano de 1921, o relato impressionista parte do espaço externo dos jardins e parques para introduzir a cidade antropomorfizada, Pauliceia. Nela, o monumento poderia celebrar a glória das bandeiras, revigorando Chagas, o Aleijadinho, Mestre Valentim, ápices da escultura nacional, e se unir aos expoentes dessa arte, na modernidade europeia - "Bourdelle, Lembruck, Carl Millès e Mestrovic".

$\mathrm{O}$ modo de informar é o modo de formar. O projeto de Brecheret não sofre descrição técnica; o cronista não fotografa, para seus leitores, a distribuição exata das massas. Busca a concepção e não poupa adjetivos para, através das impressões que a maquete do monumento lhe desencadeia, desenrolar, narrador, as imagens que a composição lhe suscita, aliadas, com simplicidade, ao juízo do crítico.

Além disso, é curioso pensar que o paulista que aclama a "epopeia" delineia, mas não aprofunda as contradições das bandeiras e monções; Bilac, aliás, na primeira parte de "O caçador de esmeraldas", lembra as aldeias indígenas arrasadas pelo conquistador europeu. Ao comentar a Vitória, alegoria no grupo monumental, a crônica conclui:

E sobre o todo pairam as asas possantes da glória, que não conhece moda nem transitoriedade, mas é eterna; porque, enquanto houver brasileiro no sertão deste país, não poderá esquecer-se dessa gente ousada que no verdenegro das florestas foi um dia marcar com um rastro clamoroso de sangue nossos vastos limites interiores.

23. Na década de 1930, no Curso de filosofia e história da arte, Mário de Andrade, sem prejuízo da análise que desenvolve, empresta à sua descrição de monumentos visitados em livros essa tonalidade impressionista. Escreve, por exemplo, como quem tivesse conhecido de perto a nave de Canterbury, onde que nunca pisou. 
Mário de Andrade cronista, em novembro de 1920, ainda não atingiu a ironia amarga e moderna na qual, poeta, moldará os versos de "Tietê", demolidores, em 1922, da idealização do bandeirante. Versos que veem o monumento de Brecheret como fecho do passado e signo do presente na metrópole brasileira do século XX. Por hora, a crônica contentase em praticar o sarcasmo tendo como alvo o escultor acadêmico e o monumento que irremediavelmente representaria a Independência na capital paulistana: "O ilustre Sr. Ximenes, que de longe veio, infelicitará a colina do Ipiranga com seu colossal centro-de-mesa de porcelana de Sèvres".

\section{CARTAS PAULISTANAS}

É no segundo texto, em dezembro de 1920, no 4, ano 8 da revista, que as crônicas "De São Paulo", ao se definirem como "cartas para a Illustração Brazileira”, colocam-se claramente no propósito de persuadir, na difusão do modernismo. Enquanto narração epistolar dos acontecimentos, acercam-se do público como os "bilhetes" do cronista Coelho Neto, no passado, ou as Cartas a Crispim, de Helios, desde o princípio de outubro daquele ano de 1920, no Correio Paulistano, retratando personalidades do meio modernista ${ }^{24}$. Correspondência ativa, não discrimina, contudo, um interlocutor nem espera resposta direta. Escrita para um destinatário coletivo, anônimo, visa, nesse artifício, como as epístolas do apóstolo Paulo, associar cada leitor da revista a uma espécie de plateia, comunidade ideal fragmentada no tempo por força de um espaço dilatado - "este larguíssimo Brasil" - , no anseio de expandir o alcance da mensagem. Cartas repletas de reflexões espelham o começo da grande correspondência que o escritor trocará com intelectuais seus contemporâneos, tendo por objeto sua meditação sobre a arte e a cultura brasileira, a criação literária, os caminhos do homem; têm mais peso do que o relato dos acontecimentos cotidianos que carregam. Na verdade, as diversas facetas destas crônicas/missivas do correspondente contratado completam-se com traços da reportagem, na série que se posiciona em dezembro de 1920:

Nestas cartas para a Illustração Brazileira dois são os meus propósitos. Procurarei realizá-los pouco a pouco, se para tanto o engenho me sobrar. A

24. As "Cartas a Crispim”, num total de 12, no Correio Paulistano, vão de 4 de outubro a 21 de dezembro de 1920 (v. BARREIRINHAS. Pesquisa: fac-símile dos textos. Setor de Arquivos, IEB-USP). 
todo este larguíssimo Brasil, que a revista sem dúvida abraçará, ao mesmo tempo que tenciono mostrar o movimento artístico e literário da gente paulista, é intuito meu explicar a enigmática cidade que a todos os que a não observem amorosamente ou lhe queiram bem guarda-se num mutismo de desdém ou se entreabre num gesto de agressão.

Muito menos porém me impulsiona o desejo de elogiar que o de verificar. Não farei apologias porque me repugnam de igual maneira diatribes e descompassado louvor (ANDRADE, 1920b, s.p.).

No escopo de difundir, faz apologia, mas, à moda modernista, pois acumula os acertos da renovação; na tarefa de narrar o progresso da cidade, aceita dados do futurismo, sem adotar o figurino futurista. Esfuziante de certeza, paga o preço da transição que está vivendo: modernidade alardeada, irreverência, frases telegráficas, frases sem verbos abertas nas reticências, a descoberta da fala brasileira cosida à da permanência da linguagem do passado - português castiço, períodos longos, altissonantes, ordem inversa, palavras raras. Transição que implica, nesse instante, a difícil percepção do que, de fato, ultrapassava ingênuas projeções e a ausência de recursos para flagrar as próprias contradições. Na série "De São Paulo", pode-se bem compreender, com Ferreira Gullar, que a avaliação dos caminhos da vanguarda em um país subdesenvolvido depende diretamente do exame das características sociais e culturais da realidade ali vivida em um determinado ponto de sua história, considerando-se a arte como expressão da particularidade determinada e concreta no mundo. Nesta São Paulo de Mário e seus companheiros, a condição de modernista prendia-se às possibilidades por eles manifestadas:

Ora é o dr. Taunay que aparece nas livrarias com os seus estudos sobre a infância da cidade, escritos em legítimo português (os enfeitadinhos soluçam); já é Brecheret que expõe o projeto do Monumento aos Bandeirantes, hino nacional da raça (os Canovas sapateiam); agora é Di Cavalcanti que mostra os seus Fantoches, onde como um novo Rops ou Lautrec, irônico e brutal, observa o dia dos que vivem... de noite (os passadistas berram).

Guilherme de Almeida soçobrou em plena Pérsia do século onze. Há mais de ano que convive extasiado com astrólogos e rosais. Menotti Del Picchia, multiforme, salamandra luminosa da literatura paulista, olha a vida estendido no leito de sensualismo de Mário Mariani ou Guido da Verona; mas logo adormece e sonha trocadilhos poéticos, percorrendo as alamedas de Cambo... Trêfego, o celebrado Hélios aparece na redação de Papel e Tinta, segurando numa das mãos Laís, na outra Máscaras e Dom Juan. E tantos outros poderia citar!

Já se sente que de novo a cidade gera ideias e escolas, reatando uma tradição quase murcha, quase ofuscada totalmente pelo brilho do Rio.

Não foi por acaso que Bilac escolheu a nossa terra para dizer ao Brasil as 
suas esperanças de renovação da nacionalidade... Sente-se um ofego bíblico de criação (ANDRADE, 192ob, s. p.).

Possibilidades, neste texto, ricas quanto à coragem de expor com liberdade o pensamento, o que significa separar com simpatia o Bilac da campanha civilista e o simplesmente "Olavo" de "Via Látea". Deste se aproxima brincalhão na primeira crônica, denunciando os corroídos temas parnasianos, mas sem banir o parnasianismo da própria linguagem. E significa ousar na crítica quando, na análise relâmpago dos Fantoches, não repisa os traços do art nouveau, reconhecidos pelo próprio artista, mas ressalta a representação estilizada da morte, o macabro, assim como a ironia, a sátira e o grotesco ao ligar os desenhos do jovem Di Cavalcanti a Rops e Toulouse-Lautrec.

"De São Paulo" seleciona seu instrumento de combate. No caráter de luta assumido pelo modernismo de 1920-21, sobressai a propaganda por meio de instrumentos musicais. A trombeta de Gedeão está com Menotti, admirador do futurismo guerreiro. Mário opta pela revitalização simbólica do instrumento dos trovadores, o alaúde. Segue assim as pegadas de Alfred de Musset e as de Gonçalves Dias, que escolheram o alaúde do reforço nacional. Os dois românticos — o francês e o brasileiro -, leituras suas comprovadas nos livros em sua biblioteca, haviam se valido do alaúde para estabelecer os respectivos projetos de atualização nacionalista. Musset, em "La nuit de Mai”, legitima os temas franceses do trovadorismo medieval e exorta: "Poéte, prends ton luth, [...]" (MUSSET, 1852)25. Gonçalves Dias faz o mesmo em "Canção", nas "Poesias diversas". Está entre aqueles que deram um passo fundamental no sentido de deslocar para o Brasil a "pesquisa lírica e heróica do passado" europeu, no dizer de Antonio Candido (1964, p. 85-86). Em “Canção”, poema lido e anotado por Mário em seu exemplar de Poesias (edição de 1919), o eu lírico entrega-se a três caminhos e cada qual recebe, como meio de expressão, um instrumento: à harpa cabe a poesia religiosa; à lira, a mulher amada e ao alaúde, o Brasil:

Votei assim ao meu Deus

A minha harpa religiosa,

A ti a lyra mimosa,

O grave alaúde aos meus! (DIAS, 1919, p. 85)

25. Obra na biblioteca de Mário de Andrade.

26. Versos 29-32, destacados por MA com colchete à margem. Ambos os volumes foram fartamente anotados pelo escritor. 
Esta segunda crônica da série “De São Paulo” enfatiza:

Os palácios de mármore dos parnasianos como os fossos de carne dos realistas ruem sob o alaúde vertiginoso da mocidade alegre e triunfal... Apreensões... Rubros estandartes... Há quem prediga batalhas e sacrifícios geniais... (ANDRADE, 192ob, s. p.)

O alaúde, tornado "vertiginoso" como o novo século, logo saltará para uma poética do fragmento, arlequinal. Antecipa o "claro riso dos modernos", forma de combate modernista a ser postulada no manifesto da revista Klaxon, logo após a Semana de 22. O alaúde habitará a definição do poeta brasileiro moderno, consciente de sua mestiçagem, "primitivo de uma nova era", na profissão de fé "O trovador", em Pauliceia desvairada: "Eu sou um tupi tangendo um alaúde". A menção ao instrumento, na crônica de dezembro de 1920, faz supor a longa gestação de um postulado estético que eclodirá no "Prefácio interessantíssimo" desse mesmo livro, contagiado pelo expressionismo: o passado como "lição para se meditar". Aqui já se delineia o crivo crítico ou uma espécie de antropofagia avant la lettre, por onde passarão o reconhecimento da parcela europeia da cultura do Brasil e os "ismos" do século XX, ambicionando um caminho moderno e nacional.

Além disso, nas águas dessa crônica navegam o penumbrismo (lembrando, inclusive, Guilherme de Almeida) e, logicamente, o impressionismo; colando-se, ao que se pode imaginar (pois não remanesceram manuscritos), a versos de uma possível primeira versão de "Paisagem no 1 " de Pauliceia desvairada (ANDRADE, 2013e), posto que o trecho final guarda semelhança com o início desse poema: a instabilidade do clima, a frase telegráfica, a ação do vento cortante. Não absorve, contudo, as costureirinhas à Baudelaire e a solidariedade para com os desvalidos da sorte que incorpora uma visão de cunho expressionista, mais crítica e, portanto, moderna, ao lirismo do modernista da cidade ${ }^{27}$.

Eis os dois tempos, o da crônica:

Mas, no meio de tanta efervescência, Pauliceia tiritou de frio. Depois do verão florido em que se escancarou na última quinzena de outubro, novamente se regelava com a abertura do mês da república. Pleno inverno. Tudo se embuçava no arminho cor de cinza das neblinas, como diria o querido Gui. Uma brisa assustada navalhou a epiderme das ruas e estremeceram no

27. Comungo a diferenciação que Henri Lefebvre faz de modernista e moderno, em Introdução à modernidade (tradução de Jehovanira Chrysóstomo de Souza; Rio de Janeiro, Paz e Terra, 1969. p. 4). 
espaço grossas gotas de orvalho, onde uma luz desfeita e multicor era como que uma saudade do Sol (ANDRADE, 1920b, s. p.).

E o tempo do poema que alude ao Barbeiro de Sevilha:

Minha Londres das neblinas finas!

Pleno verão. Os dez mil milhões de rosas paulistanas.

Há neve de perfumes no ar.

Faz frio, muito frio...

E a ironia das pernas das costureirinhas

Parecidas com bailarinas...

O vento é como uma navalha

Nas mãos de um espanhol. Arlequinal!...

Há duas horas queimou Sol.

Daqui a duas horas queima Sol. [1922]

(ANDRADE, 2013e, v. 1-10)

\section{CONTRADIÇÃO OU AVANÇO POSSÍVEL?}

Em fevereiro de 1921, no ㄲo 6 da Illustração Brazileira, na série "De São Paulo", a crônica se reconhece como tal e usa a carta como veículo de uma reflexão sobre a arquitetura brasileira, aproveitando um acontecimento na cidade para reiterar ideias expostas em "A arte religiosa no Brasil" e sua adesão à campanha pelo estilo neocolonial. Cronista assentado no presente, o assunto de Mário de Andrade é a sua surpresa ante a nova sede da Banca Francese e Italiana, na rua Quinze de Novembro, após a retirada do tapume ${ }^{28}$. No princípio do texto, reminiscências pessoais retardam a exploração do fato, pois o modernista sabe bem onde pisa. Como correspondente, deseja exibir a face do progresso da metrópole; todavia, não se deixa enganar com manifestações de pujança desvinculadas da renovação. Matreiro propagandista de São Paulo e das próprias posições, toma a análise do projeto do prédio como pretexto para uma demonstração de alto conhecimento da arquitetura do passado, novamente viajante à roda de seus livros. A valorização do estilo renascentista italiano (que fora atual in illo tempore) faculta-lhe, por meio do contraste com o presente prosaico, ironizar o edifício e o banco, deixando implícita a censura à razão de ser dos bancos em geral. E compartir com os leitores seu anseio - a viabilidade da arquitetura neocolonial. Veja-se a análise:

28. Os múltiplos títulos em italiano de lojas, bancos, clubes etc., na Pauliceia, sofreram tradução obrigatória durante a Segunda Guerra Mundial, quando o Brasil se tornou adversário da Itália. 
[...] É bem uma inspiração e não uma imitação do estilo florentino, dos princípios da Renascença, ainda saudoso do gótico nas rendilhadas janelas com possantes colunas que relembram as da escadaria do palácio Davanzati. O largo teto debruçado sobre a rua inspirou-se mais diretamente na Reggia del Bigallo, assim como os almofadões salientes da fachada transportam-nos mais para dentro do século quinze, recordando as obras de Michellozzo, Da Maiano, Cronaca. É um monumento imponentíssimo, embora, por se cingir demasiado a uma época em excesso de nós longínqua, seja um pouco frio e exagerado. Um pouco frio... Valeria mais dizer morno. O que me irrita sobremaneira na atual habitação da Banca Francese e Italiana é a quantidade das lanternas que lhe iluminam o rosto. É o caso da educadíssima e linda moça que, fantasiando-se de Gioconda, passou um baile inteiro às gargalhadas, só porque a inspiradora de Da Vinci sorria... Seguem nas linhas gerais a célebre lanterna de Nicolò Grosso Caparra, desse milagre de proporção e grandeza que é o palácio Strozzi. Eu não sei muito bem que heróicos serviços tenha prestado a Banca, nem a qual das pátrias os prestou, se à França, à Itália ou ao Brasil... Nos tempos augustos de Florença, quando exteriormente a república se debatia entre lutas e ambições, enquanto a cidade toda se engalanava de carnavais brilhantíssimos, porque

"Di doman non c’é certezza",

só podiam ter lanternas na frontaria das suas mansões os senhores nobilitados pelo heroísmo, dos quais, pela ousadia do seu sacrifícios ou temeridades das suas empresas, a pátria era credora de galardões. Hoje um banco, por sua alta recreação, borda com lanternas todos os andares e o alto da sua residência, quando Américo Vespúcio só tinha uma no seu lar, em Borgo Ognissanti!... Permitam-me os leitores da Illustração Brazileira que só mais uma vez, a última do mundo, me seja permitido o: Tempora mutantur!... (ANDRADE, 1921a, s. p.).

Feita a comparação, outra vez o correspondente se detém na retirada dos andaimes, fato que poderia lhe fornecer "assunto mais que suficiente para uma crônica". Brinca, à guisa de aquecimento ou intervalo, com associações que tocam andaimes, casas e bairros para, enfim, pôr a crônica a serviço da mensagem que deseja espalhar. Ataca a mistura de estilos europeus do passado imposta à arquitetura da cidade e novamente rejeita a secessão alemã. A mistura e o ecletismo oriundos da imigração incomodam o sofisticado observador. Não pretende negar essa marca das cidades cosmopolitas, mas não se furta à análise, nem silencia a vontade de ver instituído o acréscimo brasileiro que crê pertinente, lição do passado digna do mundo moderno - o estilo neocolonial.

Aquele que defendera o despojamento na arte de Brecheret e que, nas revistas Deutsche Kunst und Dekoration e L'Esprit Nouveau, começava a descobrir a simplicidade funcional na arquitetura do século XX, confirma a simplicidade na edificação colonial brasileira, reputando-a mais adequada ao nosso clima e à nossa condição. Ao trazer à baila a busca de um caminho brasileiro, supõe na possibilidade de alargar a perspectiva 
de Severo, presa ao traçado português. Na conversa leve cabe ao cronista informar e argumentar, para convencer seus leitores:

Mas o que há de mais glorioso para nós é o novo estilo neocolonial, que um grupo de arquitetos nacionais e portugueses, com o Sr. Ricardo Severo à frente, procura lançar. Há já exemplares interessantíssimos e a residência do Sr. Numa de Oliveira é uma obra-prima. Não me consta que já tenha havido no Brasil uma tentativa de nacionalizar a arquitetura, estilizando e aproveitando os motivos que nos apresenta o nosso pequeno passado artístico, e formando construções mais adaptadas ao meio. Ouvi dizer que Hercules Florence fez uma vez uma comunicação a uma sociedade de engenharia italiana sobre mais uma ordem arquitetônica inventada por ele, estilizando o estípite da palmeira... E é só. O neocolonial que por aqui se discute é infinitamente mais audaz e de maior alcance. Se o público, bastante educado, ajudar a interessante iniciativa, teremos ao menos para a edificação particular (e é o que importa) um estilo nosso, bem mais grato ao nosso olhar, hereditariamente saudoso de linhas anciãs e próprio ao nosso clima e ao nosso passado.

São Paulo será a fonte dum estilo brasileiro. Estou convencido de que não, mas creio firme e gostosamente que sim. Perdoem-me esta frase que mais parece de Hegel ou de Benedetto Croce. Quero crer que São Paulo será o berço duma fórmula de arte brasileira porque é bom acreditar em alguma cousa. Não sou crítico nem filósofo: sou cronista. Ah! deixem-me sonhar. Deixem-me crer que embora perturbado pela diversidade das raças que nele avultam, pela facilidade de comunicação com os outros povos, pela vontade de ser atual, europeu e futurista, o meu estado vai dar um estilo arquitetônico ao meu Brasil. Ah! deixem-me sonhar!... (ANDRADE, 1921a, s. p.).

Logo mais, em 1925, elogiará a casa modernista de Warchavchik funcional, despida de ornamentos convencionais - , e o pavilhão com afrescos de Segall, nos jardins de D. Olívia Guedes Penteado. E, em 1929, em sua coluna "Táxi” do Diário Nacional, na crônica "Le Corbusier", validará a visita do grande arquiteto à capital paulista, asseverando que a arquitetura moderna daquele momento carecia de grandes edifícios que a fizessem definitiva na consciência social do brasileiro (ANDRADE, 1976, p. 161-162 $)^{29}$. Quer que o país assimile a lição do grande arquiteto francês e, plenamente atualizado, cita Gropius na Bauhaus.

Como se vê, em 1921, a coerência do modernista não se afoga, considerados os recursos de análise que ele possui naquele momento. Recorrer ao passado colonial, no intuito de sacar uma resposta brasileira à arquitetura europeia dos mais diversos estilos do passado ou típica dos países de origem dos imigrantes enriquecidos, vigente na cidade, conforma uma aparente contradição em um acidentado percurso rumo

29. "Le Corbusier", crônica publicada no Diário Nacional, São Paulo, 21 de novembro, 1929. 
à modernidade. Este avanço possível da consciência estética de Mário faz com que se compreenda também o descompasso entre os projetos dos arquitetos e as obras dos artistas plásticos na exposição no Teatro Municipal, da Semana de 22.

Em 1942, na conferência "O movimento modernista", feita no Rio de Janeiro a convite da Casa do Estudante do Brasil, Mário de Andrade avalia a assimilação das vanguardas europeias do século XX como decisiva para a atualização de nossa arte e de nossa literatura. E defende os renovadores da pecha de europeizados e antitradicionalistas, ao relembrar as intenções da Revista do Brasil, de Lobato editor, assim como "a arquitetura e até o urbanismo (Dubugras) neocolonial, nascidos em São Paulo", como legítimos antecedentes do nacionalismo modernista (ANDRADE, s.d., p. 235).

Resta, observando a "De São Paulo" publicada em fevereiro de 1921, comentar a inclusão do verso "Di doman non c'è certezza", que calça o magnífico passeggio do viajante leitor pela Florença do renascimento. Sua erudição e ironia desnudam a passadismo e o kitsch no gosto dos imigrantes ricos. O verso extraído da primeira quadra ou mote do "Trionfo di Bacco e d' Ariana - ritornello", nos Canti carnacialeschi de Lorenzo de' Medici -

\author{
Quant'è bella Giovinezza \\ Che si fugge tuttavia \\ Chi vuol esser lieto, sia \\ Di doman non c'è certezza ${ }^{30}-$,
}

franqueia o celeiro da criação de Mário de Andrade, sua biblioteca. Então, no poema renascentista, às páginas 23-24 do exemplar do livro editado em 1883, percebe-se, latente em 1921, a matriz do poema "Carnaval carioca”. Este, também um cortejo, desabrochará em fevereiro de $1923^{31}$.

30. Devo a Jorge Coli a identificação da autoria do verso. Na biblioteca de Mário de Andrade está a obra de Lorenzo de Medici, Canti carnacialeschi e di altri poeti dei secoli XV e XVI. Prefácio: Massimo Bontempelli. Milano: Editoriale Italiano, s.d. (ref. à última ed. 1883; $1^{\circ}$. Coleta: 1559 ) - Retrato por Vasari ( Biblioteca dei Classici).

31. Na carta atestada como de [fevereiro de 1923], Mário comunica a Manuel Bandeira a criação de "Carnaval carioca"; em 22 [de abril], envia-lhe uma provável primeira versão do poema (v. MORAES, 200o, p. 84-85, 87-88, 144-147). O poema sai em Clã do jabuti, livro, na edição paga pelo autor no Estabelecimento Gráfico de Eugenio Cupolo, em São Paulo, 1927. 
8o - Remate de Males 33.1-2

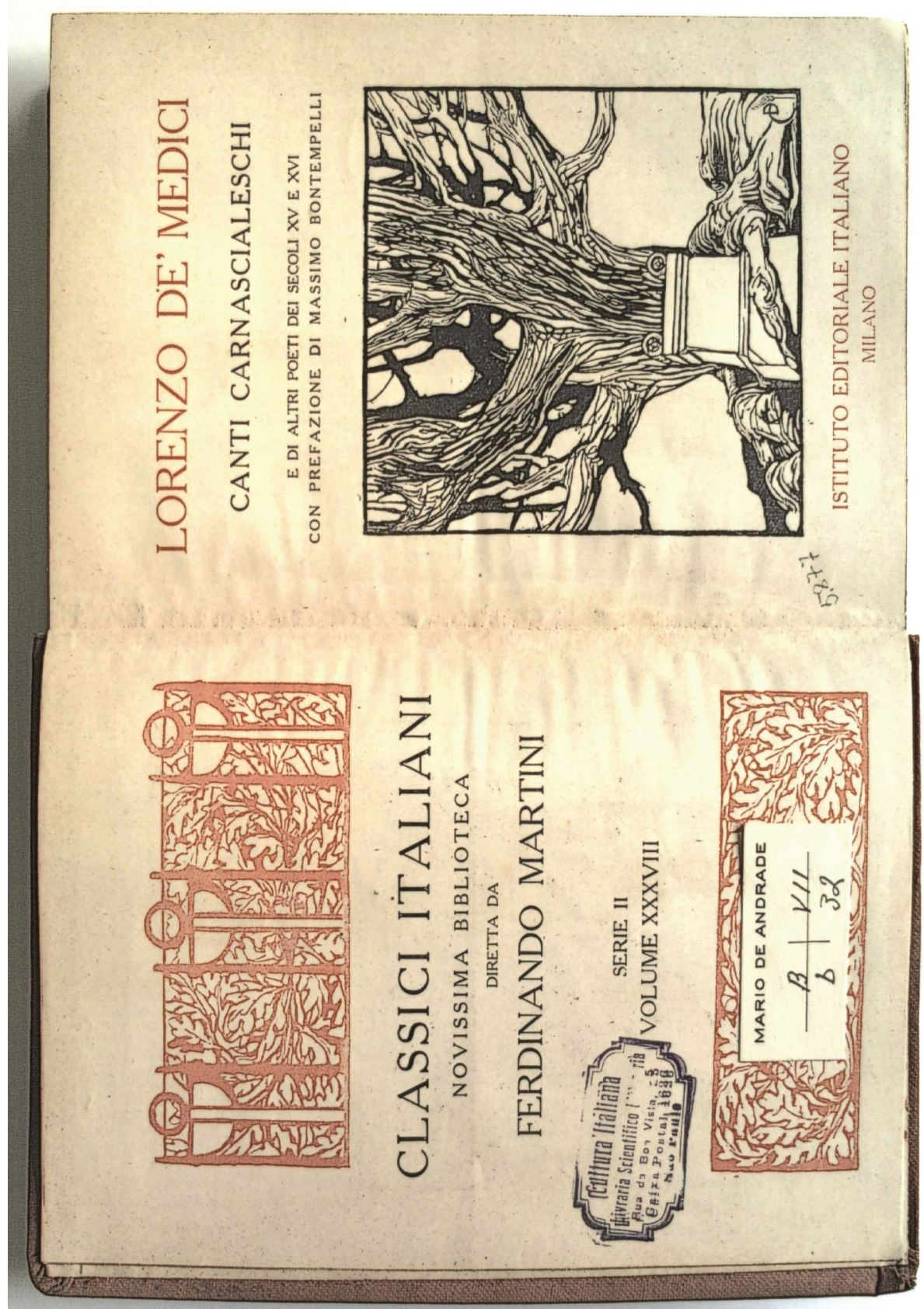

Lorenzo de Médici na biblioteca de Mário de Andrade. 


\section{NO TRIANON: TRISTURA DE PIERRÔ X AUDÁCIA VERTICAL DOS ARLEQUINS}

Na série "De São Paulo", em março de 1921, na Illustração Brazileira (ano 8, no 7), a crônica de Mário enquanto relato histórico de cunho impressionista reporta-se ao lançamento, em almoço no Trianon, da edição de luxo de As máscaras, prosa poética de Menotti del Picchia com ilustrações art nouveau de Paim. O banquete entroniza o retrato do poeta - Máscara - , obra de Brecheret em bronze, e, no decurso da festa, a surpresa: o lançamento público do modernismo. A saudação de Oswald de Andrade ao homenageado, conhecida como Manifesto do Trianon, arrebata "não só os ouvintes avanguardistas".

Na história ainda recente da cidade, aberta a Avenida Paulista, o Trianon, um mirante isolado em meio ao parque, passara a restaurante da moda:

Lugar de serenatas inconfessáveis... Comovidamente ousaram fazer do local habitações de pombos mais que simbólicos... Mas logo abrolhou a ideia de um restaurante... Era preciso resguardar um conforto dum whisky ou dum absinto a paisagem agreste e original... É que todas as urbs progressistas e que se orgulham de o ser almejam proporcionar, não éclogas, mas... paraísos artificiais. Fez-se o restaurante.

[...]

O Trianon hoje é uma instituição. É o cardápio, e como todos os cardápios, desilusório do ágape social da cidade. Busca-o toda a população da vila, do que se trate do comprimento de chapéu para fora até maxixe puladinho e chegadinho. Nele já se realizaram bailes, concertos, casamentos, banquetes votivos... Já se crismou até com bofetadas convencionais, puros mimos de escol de maridos tardiamente pundonorosos e outras cousinhas "mas", que não é bom esmiuçar. Só lhe falta uma cerimônia fúnebre. Esperei que a do bom pai e imperador de nossa terra e gente aí se realizasse... Desvaneceu-seme a ilusão (ANDRADE, 1921b, s. p.).

A referência aos encontros, os furtivos e o literário que se tornou o primeiro marco do modernismo, ficará no poema de abertura de Pauliceia desvairada, "Inspiração": "Bofetadas líricas no Trianon... Algodoal!..." (v. 7).

No relato do acontecimento, a irreverência irônica e sarcástica, ácida crônica social, coexiste com a apologia do modernismo na abordagem do discurso de Oswald e identifica de forma sutil as forças que ali se defrontaram. O cronista ilumina essa oposição ao aludir rápido ao trabalho de Brecheret, valor tácito, e ao se desviar da análise demorada da obra de Menotti. Evita definir As máscaras como um livro moderno e cuidar da elasticidade dos ideais que escoram a pontual propaganda realizada 
por Hélios. Menotti conta com a aceitação de um público acomodado porque se move num terreno sem perigo - o regionalismo patético de Juca Mulato, a versificação parnasiana e a temática da "belle époque", com pierrô, colombina e arlequim que não transgridem o carimbo da Commedia dell'Arte. Não experimenta, como os expressionistas e como Mário de Andrade, desprender do arlequim novas e modernas dimensões de busca e contestação. Mário, em sua estratégia de modernista, procede a louvação do correligionário; compraz-lhe trabalhar aliterações:

[...] E disse cousas lindas também, num prosar músico de raríssimo fulgor. Estou que o artista do Moisés maneja com maior perfeição a prosa do que o verso. [...] Sai-lhe a frase em melodia flexuosa. Coroa-a de finais que se espraiam largos, lentos, lânguidos como as maretas nas marés mortas de janeiro... E um ritmo estonteante, sempre vário, sempre original... É na sua prosa que Menotti cantou os seus melhores versos - aqueles que sua poética não permitiu ainda, enclausurada na prisão das regras alexandrinas (ANDRADE, 1921b, s. p.).

Os valores esposados e as contradições apreendidas saltam aos olhos. O cronista acende vários fogos: salienta o peso do grotesco na festa, assume a marginalidade de quem renova, elogia Oswald, sem resumir, porém, o conteúdo do discurso/manifesto. Na linguagem, o arrojo, a irreverência, a frase telegráfica continuam de mãos dadas com vocábulos preciosos e com a altissonância no torneio das frases, típicos de um tempo de passagem:

Vendo a expressiva interpretação que dele fez, no bronze, o Brecheret, instantâneo eu via também espalmarem-se no espaço duas quentes alas abraçantes. Menotti é a generosidade intelectual de braços sempre abertos... E mesmo nem sei se diga generosidade ou indiferença... Com o raciocínio elétrico, a clarividência estelar que o exornam, talvez seja a sua feição de espírito antes muito de desdém pela humanidade que ele já percebeu, nos seus múltiplos aspectos, boçalizada pela mesmice itinerária da vida.

Por isso a disparidade entre os convivas que festejavam Menotti Del Picchia era a mais bem acabada que nunca eu vi. Mirras de todas as crenças, padrões de todos os estilos, focinhos de todos os bairros baralhavam-se num hugoano amor pelas antíteses. [...]

Depois botaram falação. Muita coisa era digna de ser ouvida e anotada. O senhor Putteri, em nome da colônia italiana, espelhou ideias muito boas e muito sensatas. Sensatas demais até para serem lindas. O Oswaldo de Andrade falou também, representante e mandarim duma geração nova, reveladora de muito brilho e alguma esperança. Era o clarim dos futuristas, gente "do domínio da patologia” como dizem e redigem certos críticos passadistas, num afanoso rancor pelas auroras. João Miramar disse coisas lindas... O que implica dizer que não eram bem pensadas... E talvez seja verdade... Os homens do teu clã, como tu o chamaste, Oswaldo, meu Thiers, não pensam - cismam, não 
refletem - sentem. É uma estufa de poetas loucos, geração exótica, fantástica, arrepelada pelo consórcio com a garoa, a internacionalidade das nossas fábricas, com o convencionalismo ritual do meio. Neste manicômio pouco se pensa, dizem... Mas quê de sensações, quê de comoções, quê de entusiasmos, quê de luares e fogaréus, onde a cada passo se multiplica e se transfigura a Beleza - essa bem querida Errabunda entre os sarçais da Perfeição!... A prova disso: o Oswaldo de Andrade falou com a sua voz que é um sacrilégio, pois imita o místico psalmodiar beneditino, e a sala aplaudiu. Todos estavam muito satisfeitos porque se julgavam incorporados a "meia dúzia" de que falara o audaz. Se se lembrassem naquele cego momento de entusiasmo que pertencer a "meia dúzia" era cair "no domínio da patologia" talvez tirassem o corpo ao chuço do impropério... Como se a loucura não fosse defeito ou apanágio da humanidade inteira! Mas a vitória do clã está em todos terem querido fazer parte dele, não vendo o orgulho de solicitude em que se fortifica e acendra ${ }^{32}$ (ANDRADE, 1921b, s. p.).

O fecho da crônica na metáfora "lágrima verde" sanciona a consciência do descompasso, ao mesmo tempo em que, nas figuras aqui alegóricas do pierrô e do arlequim, desliza o contraponto: penumbrismo art nouveau e modernismo ou a dialética da coexistência do velho com o novo. Na "audácia vertical" cabem Oswald e os poemas de Pauliceia desvairada que nascem sob o signo do arlequim. Eis o trecho final:

Ficando para trás, no recinto já nu, eu vi que nos lábios sensuais da máscara brônzea de Hélios entreparava uma lágrima verde, vertida pelos olhos semi-abertos... E senti que pelos tempos ainda o artíficie continuará a desparzir uma leve tristura de Pierrô sobre a audácia vertical dos Arlequins (ANDRADE, 1921b, s. p.).

A lágrima verde, na qual se projeta a frustração do cronista, guarda o sentido de corrosão, azinhavre, é metáfora da decomposição, como em "O rebanho", sátira acerba aos políticos, no livro de 1922:

E as esperanças de ver tudo salvo!

Duas mil reformas, três projetos...

Emigram os futuros noturnos...

E verde, verde, verde!...

Oh! minhas alucinações! (ANDRADE, 2013b, v. 13-17)

Ou em "Os gatos”, na poesia da maturidade, em "A costela do GrãCão”, de 1933, misto de erotismo e escatologia:

32. Nas crônicas e nas cartas, Mário escreve Oswaldọ, abrasileirando o apelativo, ao mesmo tempo em que, no apelido João Miramar, refere-se ao romance modernista do qual o escritor publicara a primeira versão de capítulos em O Pirralho (São Paulo, 1917). 
Vamos enrolados pelas enxurradas

Em que boiam corpos, em que boiam os mortos,

Em que vão putrefactos milhares de gatos...

Das casas cai mentira,

Nós vamos com as enxurradas,

Com a perfeita inocência dos fenômenos da terra,

Voluptuosamente mortos,

Os sem ciência mais nenhuma de que a vida

Está horrenda, querendo ser, erguendo os rabos

Por trás da noite, em companhia dos milhões de gatos verdes.

(ANDRADE, 2013d, v. 27-36)

No tom macabro e surrealista avant la lettre da "lágrima verde", furtiva, subjaz o ceticismo do cronista que não pretende romper ajustes em um tempo de propaganda.

\section{NO OÁSIS DE VILA KYRIAL}

O "Sumário" do no 9 da Illustração Brazileira, ano 8, maio de 1921, classifica a seção "De São Paulo" como "Correspondência de Mário de Andrade". Desta vez, o ilustrador, além de se esmerar no cabeçalho e na capitular, dispõe, dentro de círculos permeando o texto, três desenhos art nouveau. O primeiro, com as iniciais "AL", apanha o gesto de aristocrática mão feminina que se prolonga em uma pluma; o segundo, assinado "Finley", toma um perfil de mulher, com minúscula paisagem ao fundo; o terceiro, sem assinatura, coloca um jarrão de flores belle époque na base de uma escadaria.

Esta última "De São Paulo" versa sobre o segundo ciclo de conferências do salão de Freitas Vale, Vila Kyrial, passando pelo átrio de uma forte sátira à futilidade no lazer da burguesia da cidade, alheio às manifestações culturais e a conversas de mais consistência. $\mathrm{O}$ tom satírico contrapõe-se ao apologético que o sucede para valorizar a burguesia culta assídua no único salão literário e artístico paulistano, aquele do mecenas José de Freitas Vale, onde há ciclos de conferências. O primeiro ciclo, em 1914, havia explorado temas bem diversificados no campo da cultura, distantes, porém, da realidade do Brasil, o que também ocorre no segundo, em 1921. Em 1920, Mário de Andrade já frequentava Vila Kyrial, conforme se vê na carta de 26 de fevereiro de seu amigo Martim Damy, convidando-o para uma reunião de "talentos magníficos, como os de Guilherme de Almeida, Martins Fontes, Felipe de Oliveira, 
Mário Sobral, em companhia de outros artistas-pintores e músicos [...]”33. Damy, do círculo familiar do mecenas, em 1919, havia lhe oferecido, com dedicatória, Le spleen de Paris de Baudelaire ${ }^{34}$. O salão refinado e eclético de Freitas Vale, que, pouco a pouco, terá ouvidos para o modernismo, atraía o jovem poeta, pelo que se depreende da dedicatória no livro: "Ao mais bizarro/ e encantador espirito/ dos moços que eu conheço./ Natal de 1919./ Damy".

O estudo de Márcia Camargos, Villa Kyrial: Crônica da belle époque paulistana (CAMARGOS, 2001), ao aprofundar a irradiação do simbolismo francês e belga em São Paulo no salão de Freitas Vale, conduz a um entendimento melhor da presença de escritores como Gustave Kahn, Stuart Merrill, Verhaeren não só nas estantes de Mário de Andrade, como na poética de Pauliceia desvairada (LOPEZ, 1996).

Nesta derradeira carta na série "De São Paulo", o cronista constata:

É o único salão organizado, o único oásis a que a gente se recolha semanalmente, livrando-se das falcatruas da vida chã. Pode muito bem ser que a ele afluam, junto conosco, pessoas cujos ideais artísticos discordem do nosso - e mesmo na Vila Kyrial há de todas as raças de arte: ultraístas extremados, com os dois pés no futuro e passadistas-múmias; mas é um salão, é um oásis; o que significa dizer que há sempre nele água límpida para os sedentos e tâmaras alimentares (ANDRADE, 1921c, s. p.).

Ali, desde 18 de março, tinha lugar o segundo ciclo de conferências que iria até 15 de junho.

Bom cronista, foge ao relatório e à notícia seca, pois não oferece datas, nem sequência precisa. Seu propósito de divulgar não ultrapassa o reconhecimento da importância da programação eclética de Freitas Vale... restrita ao círculo dos happy few:

Vai por ele agora larga agitação. É que começou uma nova série de conferências, onde literatos e artistas expõem as suas ideias e os seus princípios ou estudam as grandes figuras da arte ou da literatura.

Quase todos os trabalhos apresentados até agora são de indiscutível valor — genuínas obras de arte onde as graças duma linguagem nobre se concertam com as sutilezas do espírito e do saber. E se acrescento que se sucederão entre

33. A carta está no papel timbrado do Secretário do Ginásio da Capital do Estado, cargo ocupado por Martim Damy (Correspondência passiva; Arquivo Mário de Andrade IEB-USP). Damy, sobrinho da mulher de Freitas Vale, casou-se com uma filha natural do mecenas, Margarida, como nos conta Márcia Camargos em Villa Kyrial. Crônica da belle époque paulistana (2001, p. 94, 189).

34. Presente de Natal nesse ano, o volume miniatura encadernado em tecido (Paris, Payot \& Cie, s.d.) está na biblioteca de MA, IEB-USP. 
os conferencistas os nomes de Coelho Neto (sobre Shakespeare), Haddock Lobo (sobre a Ideia de Independência), Homero Prates (sobre Shelley), Felix de Otero (sobre Beethoven), João Gomes Júnior (sobre Nepomuceno) e outros ainda, provo não só a grandeza da empreitada, mas o seu interesse e o seu valor. E coroará a longa série Jacques D’Avray que estudará Ibsen, o criador de Peer Gynt.

A apresentação dos trabalhos se iniciou com três conferências sobre Dante. A Vila Kyrial não podia ficar indiferente ao centenário do gênio. Picarollo sobre ele falou, enaltecendo-lhe a força divina e... obrigando-nos também a verificar a força dos seus próprios conhecimentos. [...]

E já Martim Damy falou com leveza e argúcia sobre psicologia teatral; e amanhã, Agenor Barbosa falará sobre "Os poetas do subúrbio". O único salão paulistano esplende atualmente de luz e de entusiasmo. Nos seus anais, o ano de 1921 é uma vitória e um renascimento (ANDRADE, 1921c, s. p.).

Francamente, é de dar água na boca! E o modesto cronista omite a própria participação. No programa impresso, Mário de Andrade faz a quinta conferência, "Debussy e o impressionismo", entre a de Martim Damy e a de Agenor Barbosa. Vila Kyrial preserva a privacidade de seus convidados: no documento, apenas as datas e nada de endereço.

A louvação do empreendimento de Freitas Vale encerra a crônica:

E, por último, um pormenor sublime: dança-se na Vila Kyrial! Entre os artistas gesticulantes e entusiasmados há sílfides que vivem, valsando a valsa maravilhosa da inteligência e da graça. A excelentíssima senhora Chaves, a senhorinha Capote Valente, a admirável cantora Leonor de Aguiar e outras ainda... E, com a imaculada paz do seu espírito silencioso, a rainha de tantos feudatários, a senhorinha Leilah de Freitas Vale - que é como um som longínquo e longo de trompa numa tarde lenta, muito lenta... (ANDRADE, 1921c, s. p.)

E o faz na sonoridade bem simbolista que combina aliteração e assonância, aproximando-se dos versos de "O trovador" de Pauliceia desvairada que acolhem também a sinestesia: "Outras vezes é um doente, um frio/ na minha alma doente como um longo som redondo...” (ANDRADE, 2013c)

\section{CODA}

Os documentos ventilados no presente trabalho procuraram oferecer o jornalismo de Mário de Andrade comprometido com a propaganda modernista e, paralelamente, denunciar sinais difusos da gênese de Pauliceia desvairada, nesses textos em periódicos. Tais indícios duplicam o sentido de artigos e crônicas; transportam-nos para os arquivos da criação desta importante obra que, no vigésimo nono 
aniversário do autor, em outubro de 1921, já existia para a leitura dos amigos. Os cumprimentos de Menotti del Picchia, Oswald de Andrade e Armando Lemos Pamplona sancionam essa verdade, em tom de paródia: "Ao grande creador de/ "Paulicéa Desvairada"/ o desvario chromatico e floral destas/ rosas futuristas e a amizade antiga/ do/ Menotti/ Oswald e/ Pamplona/ 9/10/21 Da cidade Arlequinal"35.

\section{REFERÊNCIAS BIBLIOGRÁFICAS}

ALVARADO, Daisy V. M. Peccinini de. Brecheret: a linguagem das formas. São Paulo: Instituto Victor Brecheret, 2004.

AMARAL, Aracy. Artes plásticas na Semana de 22. São Paulo: Perspectiva, 1972.

ANDRADE, Mário de. A arte religiosa no Brasil. Revista do Brasil. São Paulo, a. 5, n. 49-50, 52, 54, jan.- fev., abr. jun. 1920a.

. Anhangabaú. In: "Pauliceia desvairada"; in: Poesias completas. Edição de texto apurado, anotada e acrescida de documentos por Tatiana Longo Figueiredo e Telê Ancona Lopez. 2 v. Rio de Janeiro: Nova Fronteira, 2013a (no prelo).

. De São Paulo. Illustração Brazileira. Rio de Janeiro, a. 8, n. 4, dez. 1920 .

. De São Paulo. Illustração Brazileira. Rio de Janeiro, a. 8, n. 6, fev. 1921 .

. De São Paulo. Illustração Brazileira. Rio de Janeiro, a. 8, n. 7, mar. 1921 b.

. De São Paulo. Illustração Brazileira. Rio de Janeiro, a. 8, n. 9, maio 1921 .

. De São Paulo. Edição organizada por Telê Ancona Lopez. São Paulo: SENAC, 2003.

. Le Corbusier. In: Táxi e crônicas no Diário Nacional. Ed. preparada por Telê Porto Ancona Lopez. São Paulo: Duas Cidades/ Secretaria de Cultura, Ciência e Tecnologia, 1976. p. 161-162.

. O movimento modernista, $2^{a}$. ed. In: Aspectos da Literatura Brasileira. São Paulo: Martins, s.d.. p. 231-255.

. O rebanho. In: "Pauliceia desvairada"; in: Poesias completas. Edição de texto apurado, anotada e acrescida de documentos por Tatiana Longo Figueiredo e Telê Ancona Lopez. 2 v. Rio de Janeiro: Nova Fronteira, 2013b (no prelo).

. Paulicea desvairada. São Paulo: Ed. do autor [Casa Mayença], 1922.

. O trovador. In: "Pauliceia desvairada"; in: Poesias completas. Edição de texto apurado, anotada e acrescida de documentos por Tatiana Longo Figueiredo e Telê Ancona Lopez. 2 v. Rio de Janeiro: Nova Fronteira, 2013c (no prelo).

. Os gatos. In: "A costela do Grã Cão". in: Poesias completas. Edição de texto apurado, anotada e acrescida de documentos por Tatiana Longo Figueiredo e Telê Ancona Lopez. 2 v. Rio de Janeiro: Nova Fronteira, 2013d (no prelo).

. Paisagem no 1. In: "Pauliceia desvairada"; in: Poesias completas. Edição de texto

35. V. Correspondência passiva na série Correspondência de Mário de Andrade, no arquivo do escritor (IEB-USP). Cartão com o monograma de Armando Lemos, datado de São Paulo, 9 out. 1921. As rosas presenteadas também aludem à poesia: "Pleno verão. Os dez mil milhões de rosas paulistanas" ("Paisagem no 1", v. 2). 
apurado, anotada e acrescida de documentos por Tatiana Longo Figueiredo e Telê Ancona Lopez. 2 v. Rio de Janeiro: Nova Fronteira, 2013e (no prelo).

. Religião. In: "Pauliceia desvairada"; in: Poesias completas. Edição de texto apurado, anotada e acrescida de documentos por Tatiana Longo Figueiredo e Telê Ancona Lopez. 2 v. Rio de Janeiro: Nova Fronteira, $2013 \mathrm{f}$ (no prelo).

. Tietê. In: "Pauliceia desvairada"; in: Poesias completas. Edição de texto apurado, anotada e acrescida de documentos por Tatiana Longo Figueiredo e Telê Ancona Lopez. 2 v. Rio de Janeiro: Nova Fronteira, $2013 \mathrm{~g}$ (no prelo).

BARREIRINHAS, Yoshie Sakyiama (Org.). O jornalismo de Menotti Del Picchia: 1920-22. Pesquisa: fac-símile dos textos. Setor de Arquivos, IEB-USP.

BATISTA, Marta Rossetti. Bandeiras de Brecheret: História de um monumento (19201953). São Paulo: Departamento do Patrimônio Histórico, 1985.

BRITO, Mário da Silva. História do modernismo brasileiro-I: antecedentes da Semana de Arte Moderna. São Paulo: Saraiva, 1958.

CAMARGOS, Marcia. Villa Kyrial. Crônica da belle époque paulistana. São Paulo: SENAC, 2001.

CANDIDO, Antonio. A vida ao rés-do chão. In: ANDRADE, Carlos Drummond de et alii. Para gostar de ler. São Paulo: Ática, 1979, p. 4-13.

. Formação da Literatura Brasileira: Momentos decisivos. $2^{a} \cdot e d$. revista, v.2. São Paulo: Martins, 1964, p. 85-86.

CARVALHO, Ricardo Souza de. Jardins modernistas. Teresa: Revista de literatura brasileira. São Paulo: Editora 34, n. 1, 2000. p. 195-214.

DEL PICCHIA, Menotti. O Gedeão do modernismo. Ed. organizada por Yoshie Sakiyama Barreirinhas. Rio de Janeiro: Civilização Brasileira, 1983.

DIAS, Antônio Gonçalves. Canção. In: Poesias, nova edição de J. Norberto de Souza Silva, v. 1. Paris: Garnier em Paris, 1919.

FARIA, Heloísa. São Paulo em papel e tinta: periodismo e vida urbana - 1890-1915. São Paulo: Educ/FAPESP, 2000.

KRONBAUER, Claudete (Org.). A arte religiosa no Brasil. São Paulo: Giordano/ Experimento, 1993.

LEFEBVRE, Henri. Introdução à modernidade. Tradução de Jehovanira Chrysóstomo de Souza. Rio de Janeiro: Paz e Terra, 1969.

LOPEZ, Telê Ancona. Arlequim e modernidade. In: Mariodeandradiando. São Paulo, HUCITEC, 1996.

. Mário de Andrade cronista do modernismo: 1920-1921. In: ANDRADE, Mário de. De São Paulo. Ed. preparada por Telê Ancona Lopez. São Paulo: Senac, 2003. 
Mário de Andrade e Brecheret nos primórdios do modernismo. Revista da USP. São Paulo: Universidade de São Paulo, n. 94. Dossiê 90 anos da Semana de Arte Moderna, p. 29-38, jun.- jul. 2012.

. Preludes to Modernism in Brazil. Tradução de Peter James Harris. ABEI Journal: The Brazilian Journal of Irish Studies, São Paulo, n. 4, p. 169-179, jun. 2002.

MARTINS, Ana Luiza: Revistas em revista: imprensa e práticas culturais em tempos de República (1890-1922). São Paulo: Edusp, 2001.

MEDICI, Lorenzo de. Canti carnacialeschi e di altri poeti dei secoli XV e XVI. Prefácio: Massimo Bontempelli. Milano: Editoriale Italiano, s.d.

MORAES, Marcos Antonio de (Org.). Correspondência Mário de Andrade E Manuel Bandeira. Introdução e notas Marcos Antonio de Moraes. São Paulo: Editora da Universidade de São Paulo/ Instituto de Estudos Brasileiros da Universidade de São Paulo, 200o.

MUSSET, Alfred de. La nuit de Mai. In: "Poésies nouvelles"; in. Oeuvres completes, v. 2, nouvelle édition de Edmond Biré. Paris: Garnier Frères, 1852.

SANTOS, Carla Aparecida dos. Centenário da Independência: A construção de um monumento. Histórica, no 7. São Paulo: Arquivo do Estado de São Paulo, 2002, p. 47-50.

TOLEDO, Benedito Lima de. Álbum iconográfico da Avenida Paulista. São Paulo: ExLibris/ João Fortes Engenharia, 1987.

VEIGA MIRANDA. Há uma gota de sangue em cada poema. Pocai \& C., 1917. Jornal do Comércio. São Paulo, 15 de agosto, 1917. Série Matéria extraída de periódicos; Arquivo Mário de Andrade. 
